\title{
भै \\ As mecânicas de Galileu: as máquinas simples e a perspectiva técnica moderna
}

Pablo Rubén Marigonda

\section{ComposiçÃo E DifUSÃo do TRATAdo SOBRE AS MÁQUiNAS SIMPLES}

O tratado mecânico de autoria de Galileu Galilei, que publicamos a seguir, referido pelo próprio autor como As mecânicas (Le mecaniche), consistiu originalmente de textos manuscritos, cujas cópias obtiveram ampla circulação na Europa na primeira metade do século xviı, tanto que o texto foi publicado em versão francesa por Marin Mersenne com o título Les mechaniques de Galilée, em 1634, um ano após a condenação de Galileu pelo Santo Ofício. Foi somente em 1649, sete anos após a morte de Galileu, que Luca Danesi publicou uma versão italiana, impressa em Ravena, mas, como procurasse fazer crer que havia compilado o tratado a partir dos escritos de Galileu, Danesi produziu alterações no texto, comprometendo seriamente sua autenticidade (cf. Favaro, 1933 [1891], p. 153). Foi somente na última década do século xix que Antonio Favaro examinou detidamente o conjunto de manuscritos existentes até aquele momento, conseguindo estabelecer que a cópia mais antiga datava de 1602, sem que se pudesse saber tratar-se de uma cópia direta do manuscrito autógrafo de Galileu, que já então se encontrava perdido. Trabalhando comparativamente com o conjunto de manuscritos do século xviI, Antonio Favaro estabeleceu o texto que publicou em 1891 no segundo volume de sua monumental edição das obras completas de Galileu (cf. EN, 2).

Entretanto, sete anos depois, em 1898, chegou às mãos de Favaro um manuscrito mais curto, que continha uma versão diferente, mais breve, do mesmo tratado sobre as máquinas e que trazia a data de 1594. Esse manuscrito foi chamado, segundo a cidade em que se encontrava, como manuscrito de Ratisbona (Regensburg) (Galilei, 1899 [1594]), foi publicado por Favaro no final do século xIx (cf. Drake, 1958, p. 262-4; Gatto, 2001b, p. 206-7). Outros dois manuscritos da versão breve foram posteriormente redescobertos no século xx. O manuscrito de Hamburgo, da Staats-und Universitäts-Bibliothek Hamburg, identificado por Emil Wohlwill em 1909 (cf. Drake, 1958, p. 288-9o; Gatto, 2001b, p. 210) e o manuscrito de Pasadena, identificado em 1955 por 
Stillman Drake, que propôs logo depois uma reconstrução da versão breve, tendo por base os manuscritos de Ratisbona e de Pasadena (cf. Drake, 1958). Isso consolidou a existência de uma primeira versão do texto de Galileu. Com efeito, atualmente dispomos de três cópias da versão breve e 17 cópias da versão longa de um mesmo tratado de Galileu, do qual não sobreviveu qualquer manuscrito autógrafo.

Diante disso, é possível dizer com razoável segurança que o texto de Galileu sobre as máquinas circulou manuscrito em muitas cópias, nem todas de boa qualidade, aparentemente a partir de duas versões diferentes, feitas em épocas diferentes. Evidentemente, isso permite levantar várias questões intimamente vinculadas, a saber, qual a relação existente entre as duas versões? Qual a respectiva data de composição? Para que fins aparentes foram compostos? Que tipo de ensinamento Galileu pretendia oferecer com eles? Para que tipo de instrução eles serviam ou foram usados? E finalmente por que Galileu não se preocupou em publicá-las?

Em primeiro lugar, cabe notar uma diferença clara de elaboração entre as duas versões, responsável também pela clara anterioridade da versão breve. Nesta, falta a parte introdutória sobre a natureza das máquinas e também a fundamentação teórica, além de que as cinco divisas mecânicas tratadas (balança, alavanca, cabrestante, parafuso, talha) são apresentadas com um estilo híbrido que mistura o modo de exposição das Questões mecânicas de Aristóteles, no qual os capítulos são organizados em torno das soluções para problemas ${ }^{\mathbf{1}}$ mecânicos com o modo de exposição do "teatro de máquinas" renascentista, onde cada máquina é exposta independentemente como um exemplar único, mediante a apresentação de um esquema (desenho) e uma prova, sem que fique clara a existência de um princípio comum (ou mesmo porque ele não é necessário para esse estilo de exposição), de modo que o método geral de prova se assemelha ao da dedução natural, trabalhando a partir de premissas adequadas aos desenhos, tomadas como hipóteses. A versão longa, entretanto, é mais elaborada; possui uma introdução sobre a natureza e a utilidade das máquinas, à qual segue a fundamentação teórica com definições explícitas e formulação do princípio único; seguem as máquinas (a balança romana, a alavanca, o eixo da roda, o cabrestante, a polia e talha, a cunha, o parafuso, a cóclea de Arquimedes para elevar água), cujos princípios de funcionamento são deduzidos das definições e do princípio. A exposição é aqui sistemática e dedutiva. Evidentemente a análise comparativa entre as duas versões tem um interesse intrínseco para os intérpretes de Galileu, uma vez que permite apreciar a constituição e o desenvolvimento de seu pensamento mecânico tal como se expressa

1 Aqui a distinção entre teorema e problema é extremamente relevante. Grosso modo, assim como o aspecto construtivo envolvido na solução de problemas geométricos está para a existência do objeto geométrico construído, assim também o aspecto produtivo envolvido na solução de problemas técnicos está para a construção do objeto técnico. 
na passagem da versão breve à versão longa, a qual transpõe o umbral da modernidade para fundar, como se mostrará a seguir, a engenharia moderna. Assim, para nosso propósito, que é o de introduzir a versão longa que publicamos a seguir, é suficiente a afirmação da anterioridade da versão breve e a caracterização genérica de que nos encontramos diante de dois níveis diferentes de elaboração das idéias mecânicas de Galileu. ${ }^{2}$

Questões inter-relacionadas mais difíceis de responder são as da época de composição do texto e o fim a que estava destinado. Todos os intérpretes são unânimes em considerar que As mecânicas foram compostas por Galileu na década de 1590, mais provavelmente entre os anos de 1592 e 1599, que correspondem à primeira fase de seu ensino na Universidade de Pádua, que se estendeu até o retorno de Galileu a Florença em 1610. A dificuldade está em que a determinação da data do texto está intimamente vinculada aos interesses práticos e instrutivos, que motivaram a atividade técnica desenvolvida por Galileu desde $15^{8} 7$, como parte de sua adesão explícita à profissão de matemático. ${ }^{3}$

É difícil saber até que ponto havia interligação entre sua atividade técnica e o ensino universitário. Os registros de ambas as atividades são lacunares, mas podem ser usados complementarmente na reconstrução da atividade desenvolvida por Galileu no período que vai de $15^{8} 7$ a 1610 , que se caracteriza por uma intensa atividade na direção da instrumentação científica, desenvolvendo a balança hidrostática, o compasso geométrico-militar, o termômetro (que conduzirá mais tarde pelas mãos de Torricelli ao barômetro), o microscópio, o relógio a pêndulo e, finalmente, o telescópio. Também está presente em Galileu durante esse período a obrigação a uma tarefa normalmente designada aos matemáticos nas cortes renascentistas: a de servir como engenheiros militares; do que são prova, no caso de Galileu, os tratados sobre a arquitetura militar e fortificações, além do próprio desenvolvimento do compasso geométrico-militar como uma divisa de cálculo rápido para as operações de artilharia. Evidentemente, a esta atividade técnica mesclam-se os interesses propriamente científicos de Galileu que se concentravam na solução de dois problemas mecânicos tradicionalmente considerados como fundamentais para a questão do movimento: a queda livre dos corpos e o movimento dos projéteis, problemas que Galileu abordou no período sob intensa elaboração experimental com planos inclinados, pêndulos, polias, percussão e magnetos.

2 Para proceder ao exame comparativo das duas versões do texto de Galileu, pode-se agora recorrer à edição de Romano Gatto de As mecânicas (Galilei, 2002).

3 Convém lembrar que Galileu conseguiu suas duas cátedras de matemático, primeiro em Pisa de 1589 a 1591, depois em Pádua de 1592-1610, graças à indicação do marquês Guidobaldo Del Monte, importante matemático quinhentista, que publicou em 1577, em latim, um tratado de mecânica, traduzido para o italiano em 1581 (cf. Drake, 1988, p. 69-70), sob o título de Le meccaniche, o qual é um dos trabalhos antecessores do de Galileu, aqui publicado. 
Apesar disso, é significativo que, na tentativa de datar a época de composição do texto das mecânicas, intérpretes importantes - de Antonio Favaro no século xIx até Romano Gatto no alvorecer do século xxI -, mesmo reconhecendo que Galileu utilizava o texto para o ensino particular e técnico, dedicado principalmente à instrução militar, tomam como parâmetro o ensino universitário, em particular, os registros acadêmicos da Universidade de Pádua. Assim, Antonio Favaro, após lembrar que, no ano letivo de $1597^{-1} 59^{8}$, Galileu ensinou sobre as Questões mecânicas de Aristóteles, afirma que "é provável que o Tratado de mecânica (...) do qual o autor se serviu, se não para o ensino público, certamente para o ensino privado, tenha sido produzido na ocasião em que Galileu ensinava mecânica na universidade" (cf. Favaro, 1933 [1891], p. 149). Entretanto, sem outra justificativa além da de estar de acordo com o Racconto istorico de Viviani (cf. EN, 19), Favaro toma 1593 como a data mais provável de composição da versão longa do tratado, única versão que Favaro conhecia em 1891, data de publicação da EN. Romano Gatto, ${ }^{4}$ de sua parte, segue a perspectiva de interpretação de Favaro de tomar como parâmetro a atividade docente universitária, procurando, nos registros curriculares da Universidade de Pádua, uma justificação para a datação das duas versões. Conclui, então, que "a única data plausível [para a redação da versão breve] é aquela de $1592 / 1593$, primeiro ano do ensino paduano, no qual, gozando do privilégio de poder ensinar ad libitum, Galileu escolheu ensinar, juntamente com as fortificações, as mecânicas" (Gatto, 2001b, p. 209). Quanto à versão longa, após corrigir Favaro, mostrando que os registros indicam 1598/1599 como o ano do ensino sobre as Questões mecânicas de Aristóteles, Gatto indica essa data como sendo a de finalização da versão longa.

A argumentação de Gatto não é conclusiva. No caso da versão breve, porque na realidade os registros curriculares indicam somente um curso sobre fortificações, de modo que é preciso "completar" os registros, supondo que o texto de mecânica também estivesse envolvido no curso. Tampouco é conclusiva a data de 1598/1599 para a versão longa, pois as Questões mecânicas de Aristóteles são completamente superadas por As mecânicas de Galileu, do modo que o curso sobre Aristóteles bem pode ser um curso de revisão crítica e de reorganização de material, conduzindo a uma sistematização ulterior do material original de Galileu. Entretanto, esse tipo de interpretação apresenta um viés, subjacente à suposição tácita de que os textos sobre as máquinas estavam prioritariamente dirigidos ao ensino público universitário. Com isso, esvaziam a dimensão técnica das duas versões, que estavam claramente dirigidas para o ensino técnico privado de instrução militar e para o desenvolvimento da instrumentação por

4 Romano Gatto é editor de uma edição crítica em italiano das duas versões de As mecânicas, a versão longa e a versão breve (cf. Galileu, 2002; Gatto, 2002, 2001a). 
meio da produção de divisas mecânicas, das quais o compasso geométrico-militar é um exemplo. Também é preciso considerar, portanto, que as duas versões foram compostas como exposições técnicas das máquinas simples a serem utilizadas na instrução militar básica e sua difusão deu-se nessa direção eminentemente técnica.

Stillman Drake (1988) dedicou mais atenção à perspectiva técnica presente na atividade de Galileu durante o período paduano. Como consequência de sua recusa implícita de utilizar os registros dos cursos universitários como parâmetro para a datação, Drake utiliza dois procedimentos diferentes. No caso da versão breve, toma a indicação feita por Vincenzio Viviani (1933 [1691], p. 606, nota 2) de que As mecânicas foram compostas no primeiro ano da estadia paduana, 1593 , como data de composição do manuscrito de Pasadena, cujo estágio de composição parece anterior ao do manuscrito de Ratisbona, para o qual Drake utiliza a data de 1594, referida no título do próprio manuscrito (cf. Drake, 1958, p. 266). Assim, para a versão breve, Drake utiliza a data de 1593/1594, sem precisar recorrer a qualquer tipo de ensino, seja universitário, seja técnico.

Contudo, no que diz respeito à versão longa, o procedimento é outro. Drake considera que a visão tradicional, que data de 1598/1599 a versão final do tratado, está sujeita a graves dificuldades, sem dúvida, ligadas ao fato de não considerar o escrito no meio ou sistema que lhe é apropriado, ou seja, o técnico, antes que o acadêmico. Pois, com efeito, a premissa interpretativa de Drake é, de início, inteiramente diferente: "todos os documentos relativos aos primeiros anos em Pádua testemunham o seu maior interesse pelos problemas tecnológicos que pelos filosóficos” (Drake, 1988, p. 68). Portanto, está claro que para este intérprete a perspectiva na qual se deve inserir As mecânicas é a perspectiva técnica, de modo que elas foram compostas a partir de cursos particulares (pagos pelos interessados) de instrução, ministrados e escritos em língua vulgar, ou seja, em italiano, enquanto os cursos universitários em Pádua tinham na época o latim como língua obrigatória (cf. Drake, 1988, p. 69). Assim, parece que o curso universitário sobre as Quaestiones mechanichae de Aristóteles foi um curso de revisão de posições tradicionais e de exigência de elaboração teórica face aos resultados do ensino técnico empreendido paralelamente ao ensino universitário. Considerando, além disso, como parâmetro para a datação de nosso texto, o registro dos cursos particulares, ministrados por Galileu entre 1601 e 1607 , nos quais consta para o ano de 1602 um curso de mecânica com quatro estudantes (cf. Drake, 1988, p. 90-1), Drake conclui que a data da versão longa é por volta de 1601/1602; o que coincide com a data da mais antiga cópia manuscrita de que dispomos. Além disso, Drake considera, com base na correspondência de 1609 e 1610 , "não só que As mecânicas estavam completas, mas que se havia acrescentado o trabalho sobre a resistência dos materiais" (Drake, 1958, p. 266). 
Convém, entretanto, lembrar que, embora bastante plausível, tampouco a argumentação de Drake pode ser considerada conclusiva, porque assim como a fraqueza do argumento que toma a universidade como parâmetro enfrenta o problema do registro lacunar, assim também a fraqueza do argumento que toma o ensino técnico privado como parâmetro enfrenta o problema da ausência de registro sistemático para o período entre 1592 e 1601 .

Parece, portanto, que se pode manter como razoável que, entre 1593 a 1602 , Galileu chegou, por meio de sucessivas revisões e reformulações, à versão de $A s$ mecônicas que publicamos aqui, no seio de um intenso programa de desenvolvimento experimental e técnico, que envolveu inclusive, a partir de 1596, a produção de um instrumento, o compasso geométrico-militar, para o qual Galileu contrata inclusive um artesão, Antonio Mazzolini, em 1599. Esse programa técnico está, entretanto, intimamente vinculado às preocupações teóricas e científicas que se desenrolam na atividade acadêmica e universitária. As mecânicas de Galileu não podem, portanto, ser lidas unicamente sob a perspectiva científica, decorrente das exigências acadêmicas e universitárias; na verdade, o interesse científico do tratado está em seu alcance técnico, ou seja, é enquanto sistematização científica de um assunto técnico que elas têm seu maior alcance e valor.

\section{A regepção do tratado pelos Gontemporâneos de Galileu}

Um aspecto extremamente relevante de As mecânicas de Galileu é que elas oferecem uma rara oportunidade de apreciar a recepção e repercussão da investigação mecânica de Galileu entre seus contemporâneos, seja porque a única impressão que o texto recebeu durante a vida de seu autor foi, como dissemos anteriormente, aquela da tradução francesa de Mersenne em 1634, seja também porque, de certo modo, Descartes escreve seu tratado sobre as máquinas simples 5 em resposta ao pedido de Constantin Huygens para que esclareça o que, aos seus olhos, são obscuridades do tratado de Galileu.

Éverdade que a tradução de Mersenne é bastante livre e que, além disso, tal como designado na página de rosto da edição de 1634, ele faz ao texto de Galileu dez adições, compostas basicamente de comentários de duas ordens: comentários teóricos (cientí-

5 Descartes escreveu dois textos sobre as máquinas simples, ambos cartas. A primeira, dirigida a Constantin Huygens em 5 de outubro de 1637 , é publicada nesta edição como documento científico; a segunda, dirigida ao próprio Mersenne em 13 de julho de 1638, será referida mais adiante na exposição da posição de Descartes face aos desenvolvimentos mecânicos de Galileu. 
ficos) que procuram fornecer as filiações e os desenvolvimentos teóricos e comentários técnicos que introduzem novas divisas (instrumentos) ou apresentam novos desenvolvimentos e utilidades técnicas. Essas adições são significativas para avaliar o tipo de recepção alcançado pelo texto de Galileu, pois mostram como Mersenne recebe e entende que se deve desenvolver a iniciativa galileana, em dois planos: científico e técnico.

Consideremos, de início, a página de rosto da edição de Mersenne. Ela é, de certo modo, a marca da recepção técnica do tratado de Galileu. A começar pelo título do próprio Galileu, "matemático e engenheiro do duque de Florença", no qual a designação de "filósofo", enfaticamente reclamada por Galileu na carta de 1610 a Belisario Vinta, secretário do grão-duque, em vista de seus serviços, é significativamente substituída pela de "engenheiro". Além disso, Mersenne declara ter feito várias adições "úteis aos arquitetos, engenheiros, construtores de fontes, filósofos e artesãos", deixando claro o caráter prático, técnico e produtivo do tratado que publica. Mersenne

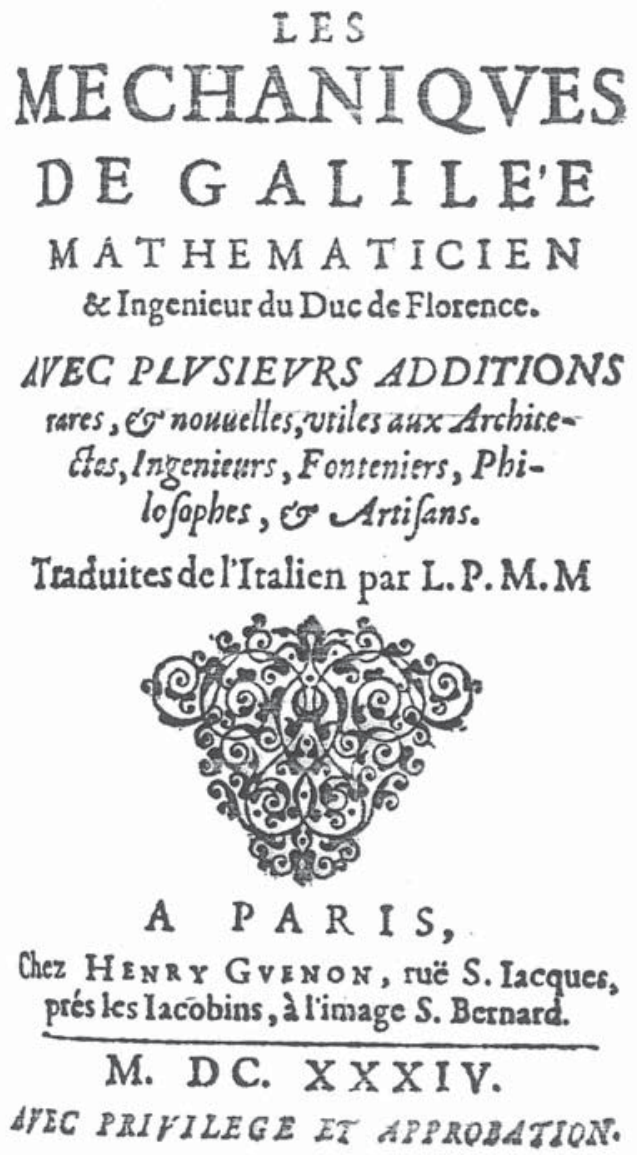

Figura 1. Página de rosto da edição francesa de $A s$ mecânicas de Galileu, traduzidas e publicadas em Paris por Marin Mersenne em 1634, um ano após a condenação de Galileu pelo Santo Ofício. não se confunde: o tratado, mais do que uma investigação científica sobre o equilíbrio dos corpos (donde parte da necessidade que Mersenne sente de complementá-lo teoricamente), é um manual técnico sobre máquinas simples. A outra parte da motivação de Mersenne está em procurar saber mais da concepção de movimento de Galileu, amplamente exposta de modo não sistemático, mas rico de detalhes, no Diálogo de 1632.

Antes de passar às adições, convém deter-se ainda na Carta dedicatória de Mersenne a certo senhor Monsieur de Reffuge, conselheiro do rei no parlamento (1966 [1634], p. 13-16), que se inicia anunciando a publicação "deste novo tratado de Galileu, que fornece novas luzes para essa ciência" e afirmando a seguir o contentamento "de ler tudo o que vem da parte deste excelente homem, que possui um dos mais sutis 
espíritos deste século" (p. 13). Mas a qual ciência se refere Mersenne? Certamente ao que ele, juntamente com Galileu e Descartes, chamam de mecânicas no plural, para designar aquela parte da mecânica que se ocupa com as máquinas, enquanto distinta da denominação no singular, mecânica, entendida como a teoria geral das condições de repouso (equilíbrio) e de movimento dos corpos físicos (naturais). Quanto às adições, segundo a dedicatória, elas "contêm novas especulações, que podem servir para penetrar os segredos da física e particularmente tudo o que concerne aos movimentos tanto naturais como violentos". Isso posto, segue uma consideração de grande relevância porque mostra que Mersenne entende perfeitamente a perspectiva científica em que Galileu se coloca:

Mas eu estimo que a ordem e ordenamento admirável que a natureza observa nas forças moventes, dar-vos-á ainda mais prazer, porque vereis reinar aqui uma equidade e uma justiça perpétua que se conserva e que se observa tão justamente entre a força, a resistência, o tempo, a velocidade e o espaço, de modo que um recompensa sempre o outro, pois se o movimento é rápido, é necessário muita força e se ele é lento, uma pequena força é suficiente. Com efeito, é impossível ganhar a força e o tempo conjuntamente... (Mersenne, 1966 [1634], p. 13-14).

Esta passagem mostra que Mersenne reconhece implicitamente o princípio das velocidades virtuais, o qual é central para a perspectiva dinâmica adotada por Galileu em seu tratamento das máquinas simples. Como veremos mais adiante, Mersenne apreende aqui o aspecto teórico mais central do tratado de Galileu, mas suas adições mostram que, no plano teórico, ele se mantém ainda preso à tradição das Questões mecânicas de Aristóteles, enquanto no plano técnico, ele se coloca claramente na perspectiva do maquinismo e do mecanicismo. Voltarei mais adiante a este assunto no contexto da recepção cartesiana.

Entretanto, Mersenne vê no tratado de Galileu muitas omissões instrumentais e dedica um quarto da dedicatória à cunha, da qual Galileu nada teria dito, ${ }^{6}$ “embora seja o instrumento mais forte de todos, pois sua força depende em parte da inclinação do plano" (p. 14). Seguindo, neste aspecto, Guidobaldo del Monte, Mersenne faz referência a toda uma família de divisas mecânicas ligadas ao plano inclinado: da faca, que utiliza o princípio da maior potência da mínima inclinação do plano de seu fio como

6 Mais adiante, na exposição do tratado, mostrarei que, no capítulo referente ao parafuso, Galileu trata do princípio que Mersenne utiliza nesta passagem, de modo que os instrumentos aqui expostos, assim como os demais que Mersenne introduzirá em suas adições, são todos, enquanto instrumentos simples, compatíveis com a teoria galileana, embora Galileu tenha optado por não expor explicitamente a cunha, talvez exatamente porque é longamente tratada por Guidobaldo em seu tratado sobre as máquinas. 
causa do cortar tão facilmente, até macacos mecânicos para levantar grandes pesos (carroças, por exemplo) por pequenas distâncias e prensas para os mais diversos fins (desde a produção de livros até a produção de óleos, vinhos, pastas etc.); como diz Mersenne, "de tudo aquilo que serve para aumentar, conservar ou diminuir a força, ou o tempo" (p. 15), de modo que, finalmente, tudo isso serve para mostrar que "as mecânicas podem ensinar a bem viver" (p. 14), facilitando tarefas que envolvem grande esforço e fadiga.

Mersenne passa depois a tratar da força de percussão em passagem que merece ser citada na íntegra:

\begin{abstract}
A força da cunha depende também da percussão, que é tão admirável que não há fardo algum, por mais pesado, que não se possa fazer mover e dirigir com golpes de martelo, por menores que estes possam ser, o que se entende que Galileu experimentou batendo tão frequentemente contra um grande cofre com um martelete, que o fez mudar de lugar, fazendo-o avançar um pé; o que muitos não acreditarão de modo algum, ainda que não se dêem ao trabalho de fazer a experiência, a qual é bastante digna de consideração, pois ela pode servir como um princípio para penetrar mais profundamente nos segredos da natureza" (Mersenne, 1966 [1634], p. 15).
\end{abstract}

Não deixa de ser interessante, neste contexto, a referência de Mersenne à suposta experiência de Galileu relativa à força de percussão, pois mostra que o papel da experiência e do experimento já era uma questão para os contemporâneos de Galileu. Entretanto, mostra também que o assunto do tratado envolve a experiência e o experimento, pois convém notar que o exemplo utilizado por Mersenne envolve repetições reiteradas e sistemáticas do ato de percussão que demanda uma observação de longo prazo do efeito. Não se trata em nada de uma observação simples mas, em sentido preciso, de um experimento planejado.

Mais significativas para a caracterização da recepção do texto galileano são as adições feitas por Mersenne a sua edição, ${ }^{7}$ as quais podem ser organizadas em dois grupos: um grupo que se pode dizer mais teórico e científico e um grupo de comentários mais técnicos. Vejamos, entretanto, qual é o plano dos comentários.

AAdição I, interposta ao final da exposição sobre os princípios, tenta esclarecer o conceito de momento, emprestando a Benedetti, Diversarum speculatinum mathematicorum et physicorum liber (Livro das diversas especulações matemáticas e físicas), 
(Torino, 1585), uma explicação em termos das propriedades dos círculos, que contrasta com a abordagem dinâmica de Galileu por estar ainda ligada ao estilo de abordagem das Questões mecânicas de Aristóteles. De qualquer modo, Mersenne fornece uma pista precisa, pois a mecânica de Benedetti é um passo importante em direção do que é desenvolvido no tratado de Galileu. A Adição ıı, interposta ao final do capítulo sobre a balança romana e a alavanca, apresenta outros dois tipos de alavancas tratadas por Guidobaldo del Monte em suas Mecânicas.

As três adições seguintes foram interpostas ao final do capítulo sobre o parafuso; destas, as duas primeiras são de certo modo teóricas. AAdição ıı discute questões vinculadas à inércia: a tendência que a esfera tem de mover-se com o mínimo de força em um plano horizontal; por outro lado, a Adição iv corresponde a um remanejamento da redação do texto de Galileu. Mersenne abrevia a passagem de Galileu sobre Pappus, para retomá-la nesta adição com uma figura e argumento que não são as do autor do tratado. A Adição v é a primeira a conter um comentário técnico e será discutida adiante, assim como a Adição vi, que foi interposta ao final do capítulo sobre a cóclea de Arquimedes, e contém um interessante comentário instrumental.

As quatro últimas adições são introduzidas por Mersenne ao final do tratado. As duas primeiras introduzem assuntos estranhos ao tratado sobre as máquinas, pois a Adição vir é relativa ao movimento, constituindo-se mais apropriadamente em suposição de Mersenne acerca de quais seriam os desenvolvimentos cinemáticos de Galileu, e a Adição vıı é uma consideração sobre o aumento de velocidade na queda livre e no plano inclinado, vinculada à exposição do que Galileu defende no Diálogo de 1632 . Estas duas adições dizem respeito de modo claro à recepção científica do tratado de Galileu, pois busca a partir do texto especular mais amplamente sobre o conjunto da investigação mecânica de Galileu, principalmente face ao Diálogo. Finalmente, as duas últimas adições - Ix e x - bem como as Adições v e vi, anteriormente referidas, constituem em conjunto a recepção técnica do tratado, da qual passo a tratar.

\subsection{A regePÇÃo tÉGniGa em Mersenne}

A Adição v considera que "a especulação dos planos diferentes é enormemente útil para encontrar a força requerida para transportar todos os tipos de fardos nas montanhas e vales e muitas outras coisas" e segue mostrando as diferenças da força no caso da manutenção do equilíbrio e nas condições de movimento da carga (p. 6o-61). Finalmente, Mersenne extrai uma consequência para a artilharia, analisando o caso da potência dos tiros de canhão contra as muralhas de uma fortaleza (p. 61-2). Tudo isso para mostrar que “é necessário tanto menos força para levantar um peso dado, quanto 
maior for o caminho da força que o do peso, a fim de que um compense o outro e que a natureza não perde nada de um lado que ela não ganha de outro" (p. 61). O comentário é interessante porque, ao tratar da artilharia, esclarece a relação do tratado com o ensino militar.

O curto comentário da Adição vi é bastante revelador da dimensão técnica da influência de Galileu, primeiro, porque faz o inventário das utilidades mecânicas que derivam da cóclea de Arquimedes, principalmente no que diz respeito "aos sifões e bombas que atraem a água e outros licores por aspiração" (p. 63), [que] "pode servir para fazer passar fontes do pé de uma montanha ou rochedo até o outro lado, para mudar o vinho e outros licores de um tonel para outro, para esvaziar as enchentes etc." (p. 64). Depois, porque introduz um comentário extremamente interessante que aponta para a importância do meio água para o uso técnico e experimental científico: assim, a água é tomada seja como fonte de energia natural, com a qual se pode mover máquinas, tais como moinhos, seja como meio que permite o desenvolvimento de instrumentos tais como a balança hidrostática que permite pesar na água a densidade específica ou peso específico dos materiais, cuja importância técnica é inquestionável e que está na base da primeira nova ciência da resistência dos materiais de Galileu. Os materiais possuem pesos específicos e é possível determinar em continuidade os seus pontos de ruptura, que são, tal como suas densidades, específicos e podem ser determinados experimentalmente.

AAdição Ix é uma exposição de instrumentos compostos de rodas dentadas e de parafusos perpétuos que se podem produzir a partir das máquinas simples de Galileu. Com efeito, como diz Mersenne, na versão (longa) que publica (cf. figura 2):

Galileu não trata dos instrumentos que se servem de rodas dentadas, como são aquelas B e A que giram por meio da manivela $\mathrm{E}$, à qual a roda menor A, que se chama ordinariamente pinhão, está ligada, a fim de acomodar seus dentes aos da grande roda $\mathrm{B}$, que gira sobre seu eixo $\mathrm{C}$, em torno do qual passa a corda que sustenta o peso D (1966 [1634], p. 74).

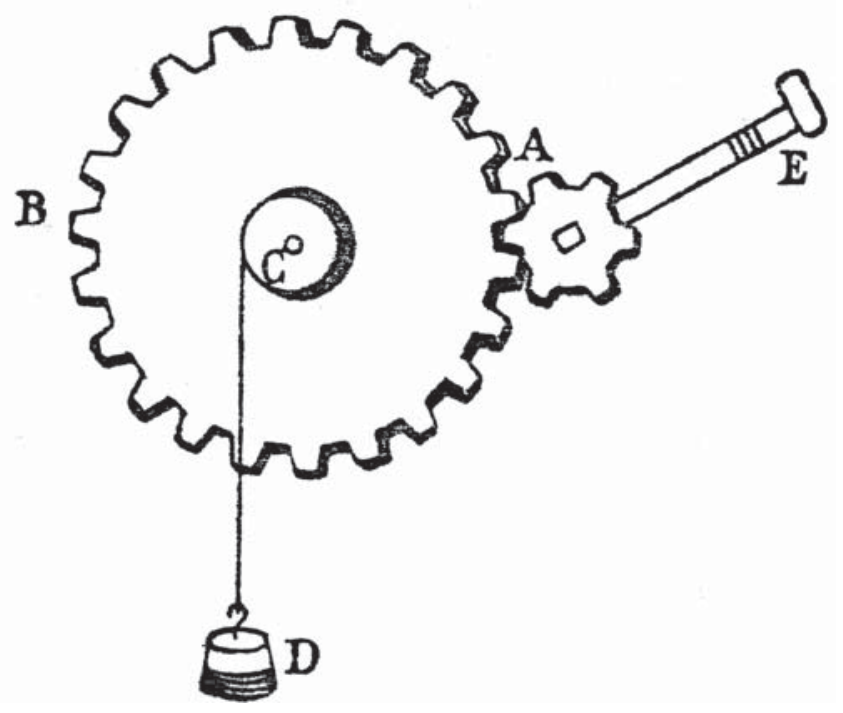

Figura 2. Mecanismo a engrenagens para relógios mecânicos apresentado por Mersenne em sua edição de 1634 , na Adição IX. 
Entretanto, este é sem dúvida o lugar para lembrar que, na versão curta, Galileu trata em capítulos separados dos instrumentos compostos de rodas dentadas e do parafuso perpétuo. Sem insistir demasiadamente neste ponto, apresento a figura do mecanismo complexo de rodas dentadas, discutido por Galileu na versão breve. Na figura 3, Galileu trata de um mecanismo desse tipo por meio do qual se multiplica a força aplicada. Vale a pena seguir sua descrição do funcionamento do mecanismo apresentado na figura, porque isso permite ver a semelhança entre as duas abordagens.

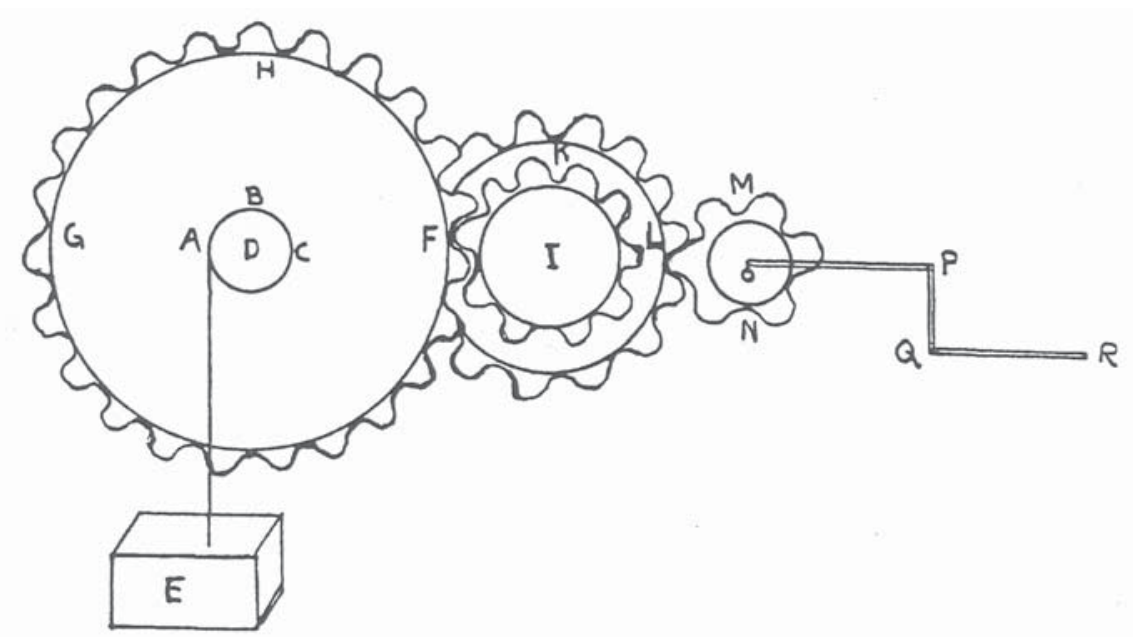

Figura 3. Diagrama de Galileu para a multiplicação e composição de rodas, descoberta atribuída a Arquimedes. Na figura, a reconstrução feita por Drake (1958).

Tomemos primeiro o eixo $A B C$ em torno do centro e perno $D$, eixo em torno do qual é passada a corda que sustenta o peso; e para girar e envolver o eixo com menor esforço, adaptemos a roda GHF e é manifesto pela natureza do eixo na roda que a força, com só esta roda, vem multiplicada segundo a proporção do raio da roda FD para o raio do eixo DA. Mas se quisermos acrescentar uma outra roda, poremos um outro eixo I, o qual girado fará mover a roda GHF, à qual se adaptará os dentes [...], depois para mover o eixo I com facilidade, ele será posto na segunda roda KL, a qual girada levará consigo o eixo I com tanto menor esforço quanto o raio da roda KL é maior que o raio do eixo I (...) (Drake, 1958, p. 283).

Ora, como se vê na figura e na descrição do mecanismo por parte de Galileu, as rodas podem ser multiplicadas o quanto se queira: "mas quanto mais rodas existem em um instrumento, mais tempo se gasta para levantar o peso ligado ao que se move 
Figura 4. Diagrama de Mersenne para um macaco mecânico utilizado para levantar e desvirar carroças. A figura menor mostra o instrumento em sua caixa. Afigura maior descreve o mecanismo interno à caixa, responsável pelo aumento da força aplicada à manivela.

mais lentamente" (p. 74). Cabe, por fim, que os instrumentos compostos aqui discutidos (figuras 2 e 3) correspondem a mecanismos básicos dos grandes relógios mecânicos que proliferaram na Europa a partir do século XIII.

Mersenne acrescenta a seguir o diagrama de um macaco mecânico (figura 4) "que serve para desvirar carroças e charretes acidentadas" (p. 75). Novamente, o que é importante na consideração está em que "se se multiplica as rodas do macaco, ele se torna tão forte que poderá levantar uma casa toda inteira, mas em recompensa seu efeito será mais tardio (p. 75).

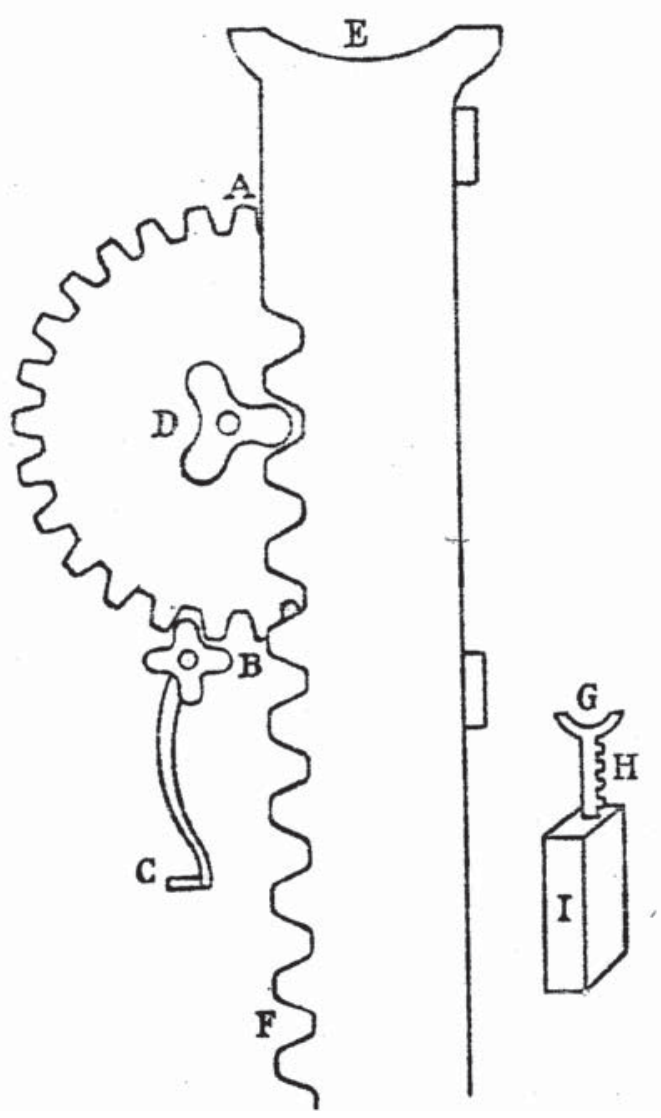

Finalmente, Mersenne chega à consideração do parafuso perpétuo como um exemplo "de rodas que possuem grande força" (p. 75), apresentando um dispositivo que serve para sustentar a carga a qualquer altura que se queira. Sua descrição do funcionamento da máquina composta apresentada na figura é:

$E F G$ é a roda maior. $A D$ é a árvore envolta de filetes $E$ que entram nos dentes dessa roda; mas se for acrescentada a roda $C B$, ela redobrará a força e a manivela $L$ fará girar a árvore $K$, cujos filetes $B$ entram nos dentes da segunda roda $B C$. $O$ peso $I$ é atado à corda $H$ e se mantém em cada grau de altura que se desejar, sem que se tenha que usar força para parar o instrumento: bastam os filetes das árvores (Mersenne, 1966 [1534], p. 76).

Figura 5. Diagrama apresentado por Mersenne na edição de 1634 para o efeito multiplicador da força que se obtém do uso do parafuso (rosca) perpétuo.

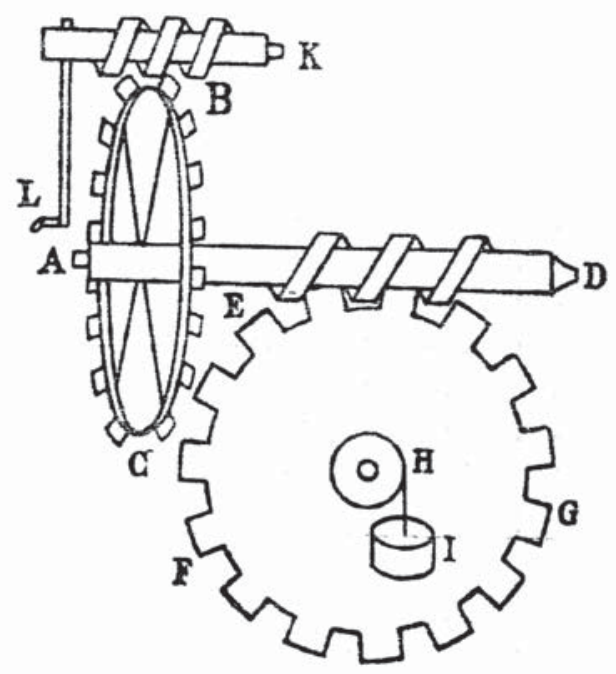


Como se vê o interesse é agora em um dispositivo de travamento capaz de sustentar uma carga a qualquer altura que se precisa fazer uso dela, o que evidentemente é muito útil na arquitetura para as construções. Entretanto, aqui também, como dissemos anteriormente, há uma discussão correspondente na versão breve de Galileu, da qual apresento o diagrama.

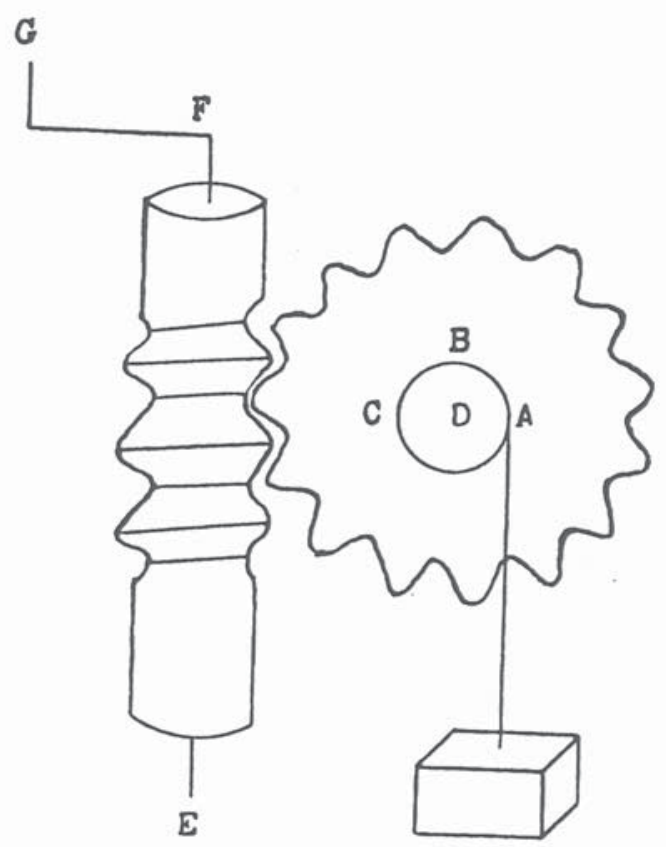

Figura 6. Diagrama para o parafuso perpétuo da versão breve de $A s$ mecânicas de Galileu, tal como reconstruído por Drake (1958).
Embora mais simples que o de Mersenne e produzido com outra finalidade, o instrumento de Galileu está composto de uma roda dentada, montada sobre um eixo ao qual está enrolado o fio que sustenta o peso, e de uma árvore à qual se adapta uma rosca sem fim (parafuso perpétuo). Notese que em ambos os instrumentos comparece também a manivela como mais um recurso para a multiplicação da força aplicada ao instrumento.

Finalmente, com relação à Adição x, se do ponto de vista científico ela bem poderia ser considerada uma curiosidade matemática, ao tratar da utilidade do triângulo retângulo para a mecânica, ela adquire maior significado quando tomada como regra técnica dirigida ao mecânico prático (cf. Mersenne, 1966 [1634], p. 77-8).

Cabe um último comentário como conclusão desta apresentação da recepção técnica de As mecânicas de Galileu na versão de 1634, de Mersenne. Tomando o conjunto dos comentários técnicos de Mersenne, percebe-se que ele apresenta um amplo leque de instrumentos para as mais diversas tarefas e utilidades. Pode-se citar, de modo relevante, utensílios tais como a faca (a partir da cunha), a grua e o guindaste (a partir do cabrestante), os sifões e as bombas (a partir da cóclea de Arquimedes), o relógio a engrenagens e o macaco mecânico (a partir de rodas e árvores dentadas), o instrumento de travamento para sustentação do peso (a partir do parafuso perpétuo). Tudo isso deixa evidente a dimensão técnica e o alcance prático do texto de Galileu na difusão que Mersenne lhe dá. 


\subsection{A regepção gientífica de As mecânicas em Mersenne e Descartes}

A recepção científica, propriamente teórica, do trabalho de Galileu é mais difícil de avaliar e é, em grande medida, externa ou transcende ao tratado sobre as máquinas simples, porque envolve, além do conjunto das investigações mecânicas de Galileu, principalmente sua exposição final, mais sistemática, nos Discorsi, que seriam publicados quatro anos depois, a difícil vinculação com a astronomia e a cosmologia do Diálogo sobre os dois máximos sistemas do mundo. Assim, a recepção científica será muito brevemente esboçada aqui, limitando-se a exposição estritamente à recepção teórica do tratado sobre as máquinas.

No que diz respeito à recepção científica do tratado por parte de Mersenne, existem basicamente três dificuldades que desafiam a apreciação da originalidade e alcance do tratamento que Galileu dá aos instrumentos simples.

Em primeiro lugar, Mersenne continua fazendo referência à tradição das Questões mecânicas de Aristóteles de reportar ao círculo as questões de equilíbrio e o princípio das velocidades virtuais, sem perceber que o tratamento galileano, em termos de momento das forças, operava uma ruptura com essa tradição. Assim, quando, nos comentários teóricos das Adições, Mersenne introduz diagramas circulares, produzindo uma prova no estilo aristotélico, ele está interpretando o princípio das velocidades virtuais dentro de um quadro conceitual, no qual esse princípio decorre das propriedades geométricas do círculo, mas o tratamento de Galileu, em termos de momentos dos pesos envolvidos, já se move em outro quadro conceitual, no qual o princípio das velocidades virtuais decorre do estabelecimento das relações entre as grandezas físicas envolvidas, a saber, força, espaço, tempo, velocidade, e supõe a idéia inercial de que um mínimo incremento diferencial de peso ou força é suficiente para que haja o rompimento da condição de repouso e o corpo se ponha em movimento. Trata-se, portanto, de dois quadros conceituais diferentes que, embora concordantes quanto à prioridade da matemática, apontam para maneiras diferentes de entender a matematização da física.

Em segundo lugar, Mersenne não consegue apreciar totalmente a diferença entre o tratamento de Guidobaldo Del Monte e o de Galileu, no que se refere à introdução do tempo e, consequentemente, da velocidade nas considerações mecânicas sobre as máquinas; ora, a introdução do tempo e a consideração dos mínimos momentos na produção do movimento são responsáveis pelo tratamento dinâmico que Galileu dá às questões de estática e envolve, neste nível, uma outra concepção de movimento.

Isso conduz à terceira dificuldade, mais propriamente matemática, da recepção científica de Galileu, não apenas no círculo de Mersenne, mas nos círculos científicos da época, que está ligada a entender o incremento de velocidade como tendo que pas- 
sar por todos os infinitos graus de velocidade que existem entre o repouso e qualquer velocidade dada. Encontram-se aqui as dificuldades ligadas ao desenvolvimento da matemática infinitesimal necessária para o entendimento galileano do princípio das velocidades virtuais e também para o desenvolvimento da ciência da resistência dos materiais na Segunda Jornada dos Discorsi de 1638.

Bastante mais complexa e indireta é a recepção científica, em particular, do texto sobre as máquinas, por parte de René Descartes. Pode-se dizer que o conjunto dos textos de Descartes que podem conduzir a uma apreciação dessa recepção está composto por dois grupos. No primeiro grupo, podemos colocar os dois textos epistolares que Descartes escreveu sobre as máquinas simples: a resposta de 5 de outubro de 1637 à carta de Constantin Huygens de 8 de setembro de 1637 (cf. AT, 1, p. 395); e a carta a Mersenne de 13 de julho de 1638. No segundo grupo, duas outras cartas, ambas endereçadas a Mersenne, de 11 de outubro e 15 de novembro de 1638 , nas quais Descartes faz referência direta a Galileu, comentando suas obras, e que, portanto, atestam que só entre novembro e dezembro de 1638, Descartes toma conhecimento do tratado de Galileu.

O primeiro grupo é relevante, porque Descartes escreve sobre o mesmo assunto que Galileu, três anos após a publicação em francês do tratado sobre as máquinas. Além disso, a carta de Huygens que deflagra, por assim dizer, a escrita cartesiana, faz referência direta a Galileu:

Se, entretanto, possuís a ocasião de alguma diversão entre o profundo estudo que imagino vos ocupar agora, eu vos rogo saber que há muito tempo tenho inveja daquele gentil homem, em favor do qual, em outra ocasião, escrevestes o Tratado de música, e pode ser que [...] me favoreçais com um tratado de três folhas sobre o assunto dos fundamentos da mecânica e os 4, ou 5 instrumentos que aí se demonstram, libra, vectis, trocleon etc. (AT, 1, p. 396).

Esta primeira parte do pedido é clara: Constantin Huygens faz um pedido explícito a Descartes, para que este escreva um Tratado de mecânica de apenas três folhas “em seu favor", isto é dedicado a Huygens. É por isso que Descartes, em sua resposta publicada aqui, diz não querer deixar de enviar o escrito como adendo à carta "uma vez que não me pedistes mais do que três folhas" (AT, 1, p. 4.35). Mas Huygens continua, como reforço para seu pedido e, sem dúvida, ele sabe bem que, para emular Descartes, para interessá-lo em tratar do assunto, nada melhor que confrontá-lo a dois reconhecidos autores no âmbito das investigações mecânicas, de quem se alega serem confusos: 
Vi outrora o que Guido Ubaldo escreveu a propósito e, depois, Galileu, traduzido por Mersenne, mas um e outro com pouca satisfação, imaginando que essas pessoas não fazem senão envolver de superfluidades obscuras uma coisa que me asseguro que compreendeis em duas ou três posições, não existindo nada neles, a meu ver, que se sustenta de uma maneira tão clara e necessária (AT, 1, p. 396-q).

Mas, com efeito, terá mesmo Huygens lido o tratado de Galileu? Porque suas afirmações não permitem entender muito bem quais são exatamente as "superfluidades obscuras" que se encontram em Galileu, de modo que nada nele se sustentaria clara e necessariamente. ${ }^{\mathbf{8}}$ A resposta de Descartes, como se pode comprovar, não faz qualquer menção a Galileu e não parece estar respondendo a qualquer ponto específico do tratado publicado por Mersenne, três anos antes. Trata-se, para Descartes, tão somente de escrever um pequeno tratado sobre os fundamentos das mecânicas e algumas aplicações simples "de somente três páginas" em favor de Constantin Huygens. A leitura do tratado de Descartes mostra, com efeito, que até este ponto ele não leu o tratado de Galileu.

O mesmo se depreende da carta a Mersenne de 13 de julho de 1638 , pois ela se dedica inteiramente a resolver uma questão central da concepção mecânica de Descartes, a de saber se um corpo grave aumenta sua gravidade à medida que se aproxima do centro e se, no centro, ele pesa mais ou menos. No seio dessa discussão, Descartes apresenta três exemplos mecânicos: a polia, o plano inclinado e a alavanca, para explicar melhor a diferença que ele estabelece entre gravidade absoluta e relativa (cf. AT, 2, p. 229). Mas novamente essa discussão não tem qualquer relação com o texto de Galileu. As exposições mecânicas dos instrumentos servem aqui ao propósito de esclarecer a distinção que é fundamental para a concepção cartesiana da gravidade.

O segundo grupo de documentos comprova a leitura tardia de Descartes, o que, além do mais, não é surpreendente, pois, como diz Rochot, "não se deve esquecer que Descartes jamais tem pressa de ler o que vem de outrem - mesmo de Galileu!" (Mersenne, 1996 [1634], p. 10, n. 2). Assim, na célebre carta de 11 de outubro de 1638, Descartes apresenta a Mersenne sua avaliação bastante negativa dos Discorsi, que acabavam de ser publicados em Leyden (cf. AT, 2, p. 380-8), que se conclui com a seguinte consideração:

Eu passo aos artigos de vossa carta [...] e primeiramente, no que se refere a Galileu, eu vos direi que eu jamais o vi, nem tive nenhuma comunicação com ele e que,

8 Quanto a essa avaliação que Huygens faz de As mecânicas e o resultado da emulação, o leitor pode avaliar por si mesmo nos dois documentos científicos publicados neste número. 
por consequência, eu não poderia ter emprestado nada dele. Tampouco vejo em seus livros o que faça inveja, nem quase nada que eu quisesse ter como meu (AT, 2, p. 388-9). 9

Esta passagem é tomada por Paul Tannery (cf. AT, 10, p. $57^{3}$ ss.) como significando que Descartes não havia lido até esse momento nada de Galileu, além dos Discorsi, do qual trata na carta. Mas Descartes está claramente falando da pessoa de Galileu; quanto aos livros, não afirma nem que os leu nem que não os leu. Afirma sim que não vê nada de importante nos escritos de Galileu, o que pode significar antes uma justificativa para o desinteresse em ler os livros, do que o resultado de uma avaliação após a leitura. De qualquer modo, o exame detalhado de todos os comentários posteriores nessa carta mostra que Descartes se atém aos Discorsi e que parece desconhecer, até essa data, As mecânicas de Galileu.

Muito mais significativa, entretanto, é a passagem da carta a Mersenne de 15 de novembro de 1638, na qual Descartes talvez faça a única referência explícita ao texto de Galileu publicado por Mersenne em 1634, nos seguintes termos:

Quanto ao escrito de Galileu relativo à balança e à alavanca, ele explica muito bem quod ita fit (o que ela faz), mas não cur ita fit (por que ela faz), como faço em meu Princípio. E para aqueles que dizem que eu devia considerar a velocidade, como Galileu, antes que o espaço, para dar conta das máquinas, eu creio, entre nós, que são pessoas que falam por fantasia, sem entender nada nesta matéria. E ainda que seja evidente que é necessário mais força para levantar um corpo muito rapidamente, que para elevá-lo lentamente, é, entretanto, uma pura imaginação dizer que a força deve ser exatamente dupla para dobrar a velocidade e é bem fácil provar o contrário (AT, 2, p. 4,33-4).

A passagem aponta significativamente para duas dificuldades de ordem teórica que Descartes vê em As mecânicas. Em primeiro lugar, Descartes aponta uma clara diferença de perspectiva. Enquanto Galileu adota a perspectiva quod ita fit (o que ela faz) de descrever a operação mecânica da máquina, Descartes afirma adotar a perspectiva

9 Descartes continua seu comentário do seguinte modo: "O melhor é o que ele tem de música, mas aqueles que me conhecem podem acreditar que ele o obteve de mim, antes que eu dele: pois escrevi quase o mesmo faz 19 anos, tempo no qual não tinha estado na Itália, e dei meu escrito ao senhor Beecman que, como sabeis, desfila escrevendo para cá e para lá, como se a coisa fosse sua" (AT, 2, p. 389). Descartes está obviamente sugerindo que Galileu teria emprestado dele o que diz a respeito de música; entretanto, as investigações sobre a música e os experimentos de tensão das cordas fazem parte da "arqueologia" galileana, uma vez que pertencem a sua infância e a sua formação no seio da família: seu pai e seu irmão eram músicos. 
cur ita fit (por que ela faz) de explicar a causa de sua operação mecânica. A dificuldade e diferença é aqui quanto à concepção de abordagem dinâmica: Galileu parece trabalhar em uma perspectiva dinâmica fenomenológica, enquanto Descartes trabalha em uma perspectiva dinâmica explicativa e, por isso, a discussão dos três instrumentos na carta de 13 de julho de 1638 está imersa na discussão sobre a ação da gravidade; por isso também a perspectiva de Galileu parece a Descartes construir sem fundamentos.

Em segundo lugar, de modo bastante direto, Descartes se refere à velocidade. Entretanto, neste caso, ele ignora primeiramente a verdadeira divergência que diz respeito à introdução de considerações temporais na estática ou, de modo mais geral, à introdução do tempo como grandeza física a ser considerada nas questões mecânicas de levantamento e sustentação de pesos e cargas, porque, sem isso, não se pode falar em velocidade, que supõe uma relação entre a distância e o tempo. Entretanto, isso só revela que parte da resistência científica ao tratado de Galileu consiste na discordância quanto ao tratamento dinâmico dado por Galileu a questões de estática ou a sua formulação infinitesimal do princípio das velocidades virtuais. Além disso, o que Descartes afirma seguir-se, ou seja, que a força deve ser dupla para dobrar a velocidade, não se encontra em Galileu, e mostra agora que ele não leu com atenção, pois não é essa a implicação da admissão do tempo como grandeza física, mas fundamentalmente, como veremos a seguir, uma modificação, do ponto de vista técnico, na concepção de máquina, que a torna apta à avaliação quantitativa com a introdução da idéia de rendimento da máquina, o que do ponto de vista científico representa uma aproximação ao conceito de trabalho.

A outra parte da resistência científica de Descartes prende-se à ausência de uma teoria geral da gravidade em Galileu, que se recusa a especular sobre a causa da gravidade, a qual é enfrentada por Descartes, resultando em uma concepção completamente diferente de centro de gravidade. Como esta discussão depende dos conceitos definidos no tratado, será abordada mais adiante na parte 3.1.2.

Finalmente, é preciso lembrar que o tratado sobre as máquinas, em virtude da data de composição (mesmo utilizando a data mais tardia de 1602), é a expressão de uma etapa do trabalho científico na qual Galileu não havia ainda resolvido o problema da aceleração da queda livre, ou seja, o problema de saber com qual proporção cresce a velocidade de um corpo que se deixa cair livremente. Ora, o texto de Galileu contém, portanto, uma limitação científica que é a de não considerar que o movimento de queda do corpo é acelerado e tratar todos os movimentos como sendo uniformes ou feitos a velocidades constantes. 


\section{A teoria da máquina simples no tratado de Galileu}

Para apreciar o alcance de As mecânicas - isto é, sua contribuição científica e técnica é preciso, ainda que breve e esquematicamente, discorrer sobre a estrutura que preside a argumentação e o desenvolvimento galileanos.

\subsection{A estrutura Geral do tratado SObre as máquinas}

Do ponto de vista da estrutura geral da argumentação empregada por Galileu, pode-se considerar que As mecânicas estão compostas de quatro partes. O tratado começa - [155] a [159] - com uma discussão introdutória sobre a utilidade das máquinas, na qual se pode apreciar a crítica de Galileu à concepção tradicional e sua versão da concepção moderna de máquina. Procede, a seguir - $\left.{ }_{15}{ }_{59}\right]$ a [165] -, à fundamentação teórica (físico-geométrica) dos instrumentos mecânicos, com a formulação das definições de gravidade, momento e centro de gravidade, e de três suposições, por meio das quais formula o princípio mecânico geral da proporcionalidade inversa entre o peso e a distância de suspensão. Provê, nas advertências - [163] a [165] -, esse princípio de uma interpretação dinâmica em termos de velocidades virtuais. As duas partes seguintes dedicam-se a desenvolver as consequências instrumentais (as aplicações) do princípio da proporcionalidade inversa entre peso e distância segundo uma estratégia expositiva que consiste em apresentar a divisa instrumental básica geradora do que se pode chamar de "famílias instrumentais". A terceira parte - [165] a [178] -, que ocupa três capítulos, desenvolve a família instrumental cujo princípio se encontra na equivalência entre o funcionamento da balança de braços desiguais e da alavanca, discorrendo sobre as próprias balança de braços desiguais (mais conhecida como balança romana) e alavanca e, depois, o funcionamento dos instrumentos que dependem da alavanca perpétua, como são a roda, o cabrestante (guindaste), a roldana e a talha. A quarta parte - [178] a [189] - apresenta o princípio instrumental do plano inclinado e a família de instrumentos que lhe estão ligados: o parafuso, a cóclea de Arquimedes. Por fim, o último capítulo sobre a força de percussão constitui uma espécie de adendo, em que Galileu tenta explicar a operação do martelo.

\subsubsection{A introduçã̃o de Galileu E a Concepção moderna de máquina}

Como logo na parte introdutória do tratado, Galileu marca seu afastamento com relação à concepção de máquina presente nas Questões mecânicas de Aristóteles, convém considerar, ainda que brevemente, a concepção tradicional de máquina exposta nesse tex- 
to pseudo-aristotélico, de modo a ressaltar a originalidade da concepção articulada por Galileu. E, com efeito, as Questões mecânicas iniciam discorrendo sobre o surpreendente das operações mecânicas, uma vez que podemos ser surpreendidos por duas coisas:

(...) primeiramente, pelas coisas que acontecem segundo a natureza, mas das quais não conhecemos a causa e, secundariamente, por aquelas que são produzidas pela arte a despeito da natureza para o benefício da humanidade. A natureza frequentemente opera contrariamente ao interesse humano, pois ela sempre segue o mesmo curso sem desvio, enquanto o interesse humano está sempre mudando. Quando, portanto, temos que fazer algo contrário à natureza, a dificuldade disso causa-nos perplexidade e a arte deve ser chamada em nossa ajuda. $\mathrm{O}$ tipo de arte que nos ajuda em tais perplexidades chamamos habilidade mecânica. (...) Exemplos disso são aqueles casos nos quais o menor prevalece sobre o maior e a força de menor potência motiva prevalece sobre a maior, e onde forças de menor potência motiva movem grandes pesos - com efeito, praticamente todos aqueles problemas que chamamos problemas mecânicos (Mech, $\left.847^{\mathrm{a}} 10-25\right)$.

Aristóteles concebe a máquina como um expediente, pelo qual resolvemos o surpreendente da dificuldade de uma situação contrária à natureza; um expediente com o qual conseguimos, de certo modo, ludibriar a natureza, enganá-la. Acontece que a concepção de máquina de Aristóteles está profundamente enraizada no sentido originário do termo máquina, que deriva do termo grego mechane, indicando originalmente o resultado de uma ação conduzida com particular eficácia e que é, por si mesma, surpreendente. Além disso, a mechane, enquanto ligada à ação, é fruto de um tipo de inteligência aguda e perspicaz, que se vale de meios não usuais, não comuns, até contra a natureza (como na citação acima), encontrados com sagacidade e intuição, para conseguir um efeito não previsível (como o curso do interesse humano). Ora, essa qualidade intelectual - esse tipo de inteligência - tem seu campo de atuação e aplicação nas atividades práticas (na caça, na pesca, na agricultura, na criação de animais, na atividade política e, de modo sempre decisivo, na guerra). Trata-se do que os gregos chamavam metis: uma capacidade intelectual (humana), pela qual, na impossibilidade de usar meios habituais ou imediatamente evidentes para resolver um problema prático, encontra com sua engenhosidade expedientes (mechanai) por meio dos quais transforma uma situação desfavorável em favorável (cf. Micheli, 1995).

Desta acepção primária derivam dois outros sentidos, que também estão presentes na citação de Aristóteles: no sentido positivo, mechane é simplesmente o meio, o instrumento, a máquina pura e simplesmente; e, também, o ato de construir objetos materiais com funções particulares, que servem para facilitar a atividade humana. 
Por outro lado, em sentido derivado negativo, mechane significa expediente, no sentido de trama, ardil ou, pura e simplesmente, maquinação, com o que se procura enganar um oponente ou adversário ou tornar favorável uma situação desfavorável. De qualquer modo, é nesta acepção negativa que se assenta a idéia de que as máquinas são expedientes - inventados por certo tipo específico de habilidade e inteligência -, que permitem enganar a natureza.

A concepção de Galileu, como veremos, é bem diferente. Galileu considera que, para tratar da utilidade das máquinas, é preciso começar afastando essa concepção enganada e enganosa de máquina, que está baseada na falsa crença "de poder com pouca força mover e levantar grandíssimos pesos, enganando, de certo modo, com suas máquinas a natureza" [155]. Para mostrar que não se engana a natureza, Galileu apresenta quatro variáveis envolvidas na situação mecânica em que uma força pequena levanta um grande peso e que é importante levar em consideração: (1) o peso a transferir, (2) a força ou potência para movê-lo, (3) a distância pela qual se deve mover o peso, (4) o tempo, no qual tal mudança deve ser feita.

Destes elementos, o mais significativo é, sem dúvida, a introdução do tempo como variável a ser considerada na situação mecânica em questão. De imediato, a introdução do tempo permite levar em consideração a velocidade em que se faz a operação instrumental, pois, como diz Galileu, o tempo "retorna na própria coisa com a presteza e velocidade do movimento, determinando-se que é mais veloz que outro aquele movimento que em menor tempo passa por distância igual" [156]. Considerar o tempo e, consequentemente, a velocidade como parte da situação é um claro indício de que Galileu dará um tratamento dinâmico às questões normalmente consideradas como de equilíbrio, ou repouso, e, portanto, estáticas. ${ }^{10}$

Mas não é só isso, porque a introdução do tempo é responsável também pela eliminação do surpreendente da situação, pois, como mostra Galileu, existe uma relação de proporcionalidade inversa entre a força empregada para deslocar um dado peso por uma dada distância e o tempo para fazê-lo, de modo que não se pode diminuir a força sem aumentar o tempo, nem diminuir o tempo sem aumentar a força. Portanto, nada há de surpreendente que uma máquina permita com pequena força levantar grandes pesos, pois o fará percorrendo uma distância tanto maior, ou em um tempo tanto maior ou tanto mais lentamente, quanto menor for a força empregada. Não há, portanto, milagre algum no funcionamento das máquinas e a natureza não é enganada; muito ao

10 A introdução do tempo como grandeza física a ser levada em consideração na situação é responsável também pela diferença entre a abordagem dinâmica de Galileu e a abordagem estática de seu protetor Guidobaldo del Monte, que se expressa justamente na negativa deste último em aceitar a introdução do tempo como elemento constitutivo de uma situação estática. 
contrário, as máquinas obedecem certas regularidades físicas perfeitamente compreensíveis para o ser humano. Assim, é precisamente porque existe uma lei de proporcionalidade inversa entre a força e o tempo que deixa de existir o surpreendente e qualquer atributo "mágico" das máquinas, que permitiria com elas enganar a natureza.

Além disso, tampouco é desprezível a diferença causada por essa racionalização da imagem de máquina quanto ao tipo de inteligência necessária para a resolução dos problemas mecânicos, porque as máquinas, que antes se atribuíam a um tipo específico de inteligência, são agora tomadas como objeto de ciência demonstrativa e racional, de modo a constituir-se em um corpo sistemático de conhecimentos aptos à instrução. O resultado é, de certo modo, que esperteza e intuição são substituídas por treinamento e instrução baseados em procedimentos repetíveis racionalmente estabelecidos.

Afastada a concepção de que as máquinas são expedientes para enganar a natureza e considerando que toda situação mecânica está presa a essa relação de mútua dependência entre força e tempo, de modo que o que se ganha em uma perde-se no outro, Galileu passa a considerar três utilidades das máquinas.

A primeira utilidade da máquina é, então, que "ocorre muitas vezes que, sendo escassa a força, mas não o tempo, ocorre-nos mover grandes pesos todos unidamente" [157] para o que utilizamos a máquina, lembrando sempre que se pode fazer o mesmo, dividindo o peso em partes e transportando cada uma dessas partes separadamente.

A segunda utilidade das máquinas "depende do lugar onde deve ser feita a operação", de modo que a utilidade das máquinas decorre do fato de que se pode adaptá-la à situação. Assim, utilizamos bombas para secar os porões dos navios, não porque elas tenham o efeito surpreendente de mover maior quantidade de água que faríamos utilizando um balde, mas porque a bomba se adapta aos pequenos cantos angulados enquanto o balde, nesses lugares, não pode ser usado.

Finalmente, a terceira utilidade diz respeito à força motriz ou, como diz Galileu [158], ao movente, porque as máquinas - no meio ou sistema técnico de Galileu - podem ser movidas por três tipos de força: por força inanimada, como o curso de um rio ou o vento, ou por força animada, seja animal (cavalo, boi etc.) ou humana. As considerações a este respeito são relevantes na nova imagem de máquina, dizem respeito ao dispêndio (spesa), pois são relativas ao que "seria necessário à manutenção da pujança humana, como quando, para mover os moinhos, servimo-nos do curso de um rio ou da força de um cavalo para fazer aquele efeito para o qual não bastaria o poder de quatro ou seis homens" [158].

Como se vê, na concepção moderna de máquina, a questão da utilização das forças motrizes naturais em proveito do homem não está ligada a qualquer consideração qualitativa sobre o efeito surpreendente ou milagroso das máquinas, mas liga-se simplesmente a uma questão de dispêndio: na medida em que as máquinas permitem usar 
as forças naturais, seu dispêndio é menor e, por isso, as utilizamos. Evidentemente, nesta concepção, ao invés da máquina ser avaliada e prezada por sua qualidade surpreendente de superação da natureza, ela é vista da perspectiva quantitativa que considera sua eficácia, não como resultado de um artifício que engana a natureza, mas em termos quantitativos de dispêndio e de rendimento. ${ }^{\mathbf{1 1}}$

É significativo que Galileu encerre sua introdução chamando a atenção de que o engenheiro deve ater-se às possibilidades, deve trabalhar no terreno do possível, respeitando aquele "curso sem desvio" da natureza, ao qual se refere Aristóteles, para do seu conhecimento extrair as aplicações possíveis e as explicações do funcionamento eficaz das máquinas. É por isso também que o engenheiro precisa saber a natureza dos instrumentos mecânicos e suas propriedades, para, reconhecidas as impossibilidades, poder fazer o melhor e mais adequado uso dos instrumentos dentro do que é permitido pela natureza.

\subsubsection{Os FUndamentos Físico-MATEmÁticos da teoria demonstrativa DE GALileu}

Uma vez estabelecido que as máquinas são objeto de conhecimento racional e que nada de extraordinário há nelas que justifique outro tratamento diferente do racional, Galileu passa à sistematização demonstrativa (dedutiva) das máquinas simples, propondo três definições e três suposições (hipóteses) a partir das quais se demonstram as causas do funcionamento e "as verdadeiras demonstrações das propriedades de todos os instrumentos mecânicos" [159]. Não é qualquer sistematização que Galileu apresenta, mas uma sistematização completa: pretende que todos os instrumentos mecânicos estão concernidos nessa sistematização demonstrativa. Esta consideração se revelará importante mais adiante para a hipótese defendida aqui de que Galileu apresenta, na verdade, dois princípios instrumentais - a alavanca e o plano inclinado - para explicar o funcionamento de todos os instrumentos mecânicos.

O conjunto das três definições é significativo. Galileu inicia com a definição de gravidade como sendo

a propensão de mover-se naturalmente para baixo, (...) causada, nos corpos sólidos, pela maior ou menor quantidade de matéria, da qual são constituídos [159].

Nesta definição, Galileu parece, por um lado, estar fazendo referência à gravidade específica (peso específico); entretanto, como restringe sua definição aos corpos 
sólidos, ${ }^{\mathbf{1 2}}$ pode-se interpretar a definição de gravidade dada aqui como expressão de um conceito que se aproxima da definição newtoniana de massa como quantidade de matéria de um corpo. Deve-se aqui notar que Galileu não possui uma teoria geral da gravidade, como é o caso de Descartes. Ao contrário deste último, Galileu abandona conscientemente a procura da causa da gravidade e concentra-se na configuração cinemática resultante da constatação empírica de que todos os corpos apresentam uma tendência de dirigir-se para o centro da Terra. Esta estratégia de investigação está claramente presente em As mecânicas e é explicitamente afirmada nos Discorsi de 1638. Assim, mesmo 36 anos mais tarde, Galileu continuará considerando que não vale a pena

a investigação da causa da aceleração do movimento natural, a respeito da qual vários filósofos apresentaram diferentes opiniões, reduzindo-a alguns à aproximação do centro; outros, à redução progressiva das partes do meio que restam ser atravessadas; outros, ainda, a certa extrusão do meio ambiente (...). Estas fantasias e muitas outras conviria serem examinadas e resolvidas com pouco proveito (Galilei, 1933 [1638], p. 202).

Da perspectiva da estratégia adotada por Galileu, trata-se antes de investigar e demonstrar, diante do fato óbvio de que todos os corpos caem em direção ao centro da Terra, as propriedades cinemáticas do movimento acelerado natural dos corpos. Assim, feita a suposição dinâmica, investiga-se o fato da queda acelerada, qualquer que seja a causa da gravidade, ou seja, qualquer que seja a causa pela qual os corpos são obrigados a dirigir-se para o centro da Terra.

Por outro lado, a estratégia adotada em As mecânicas está claramente em linha de continuidade com as primeiras realizações de Galileu as quais consistiram exatamente em investigar matematicamente, no biênio $15^{8} 7^{-1} 5^{88}$, questões relativas à determinação do centro de gravidade dos sólidos (que são básicas para a terceira definição) e em investigar experimentalmente - na verdade, realizar a operação experimental fundamental de medir -, por meio da balança hidrostática (1586), o peso específico dos materiais.

Galileu formula sua segunda definição, na qual o momento é definido como:

a propensão de ir para baixo, causada não tanto pela gravidade do móvel, quanto pela disposição que possuem entre si os diferentes corpos graves [159]. 
Como mostra Clavelin (1996, p. 160-1), Galileu está explicita e corretamente definindo a noção de momento estático; pelo menos nesta acepção que decorre imediatamente da definição e que consiste em considerar que o momento é dado pelo produto entre o peso e a distância. É esta acepção de momento que estará implicada mais adiante na descrição das máquinas simples.

Entretanto, podem-se encontrar no tratado outras duas acepções de momento, que também são frequentes em textos posteriores de Galileu: a primeira acepção toma momento como sendo o produto do peso de um corpo pela velocidade virtual de seu deslocamento; na segunda acepção, ligada à análise do plano inclinado, o momento representa em si mesmo "o aumento ou diminuição de intensidade que sofre, sobre o plano inclinado, a tendência de um grave a mover-se para baixo" (Clavelin, 1996, p. 161). De qualquer modo, estas duas acepções não possuem, no tratado das máquinas, função demonstrativa ou explicativa.

O momento estático depende, portanto, do agregado de corpos e das relações que eles mantêm entre si, constituindo-se pela combinação de gravidade e distância, de modo que um peso pequeno a grande distância do fulcro de uma balança equilibra um peso grande a pequena distância.

Finalmente, o centro de gravidade de um corpo grave é "aquele ponto em torno do qual consistem partes de igual momento" [159], de modo que, se o corpo for suspenso por esse ponto, permanecerá em equilíbrio ou repouso. Galileu alerta também que é por esse ponto que passa a linha reta pela qual os corpos graves descem em direção ao centro da Terra.

Convém aqui retornar à dificuldade científica concernente à gravidade, que afirmamos impedir Descartes de aceitar o tratamento dado por Galileu. Éfácil mostrar agora que Descartes não pode aceitar a definição acima de centro de gravidade. Com efeito, segundo sua teoria da gravidade, quanto mais um corpo está afastado do centro da Terra, menos pesado ele é e, quanto mais próximo do centro da Terra, mais pesado.

Donde se segue, como diz Descartes, que (...) entre as partes iguais de um mesmo corpo, as mais altas pesam tanto menos que as mais baixas, quanto são mais afastadas do centro da Terra, de modo que o centro de gravidade não pode ser um centro imóvel em nenhum corpo, ainda que seja esférico (AT, 2, p. 228).

Para Galileu, ao contrário, o centro de gravidade de cada corpo é único e inamovível e, como veremos, isso é importante para a idealização da situação experimental que Galileu fará a seguir e que é uma das marcas de seu estilo de fazer ciência.

Uma vez definidos gravidade, momento e centro de gravidade, Galileu formula, em [16o], as três seguintes suposições: 
(1) o movimento para baixo de um corpo percorre a linha reta que vai do centro de gravidade do corpo ao centro de gravidade comum, ou seja, o centro da Terra;

(2) redução do corpo físico ao centro de gravidade, de modo que o ímpeto, seu peso e o momento desse corpo possam ser atribuídos a esse ponto;

(3) o centro de gravidade de dois corpos igualmente graves encontra-se no meio da linha reta que une os centros de gravidade desses corpos.

Um rápido exame das suposições revela a centralidade do conceito de centro de gravidade para a idealização geométrica das questões relativas à estática e às máquinas. A idealização operada pela segunda suposição é fundamental para a geometrização do espaço e das propriedades físicas das máquinas. Os corpos físicos podem ser considerados, para efeito da sistematização dedutiva, como "pontos materiais" dotados de massa e momento. Isso permite também, na terceira suposição, traçar precisamente, isto é, como construção geométrica, a linha reta que une os dois pontos que representam os centros de gravidade dos corpos em questão.

Dadas as definições e postas as suposições, Galileu formula, utilizando seus próprios termos,

um princípio (...) de boa parte dos instrumentos mecânicos, demonstrando como pesos desiguais pendentes de distâncias desiguais pesarão igualmente, sempre que ditas distâncias tenham proporção inversa daquela que têm os pesos [161].

A primeira coisa a observar é que Galileu se refere ao princípio que apresenta como sendo um princípio "de boa parte dos instrumentos mecânicos", quando vimos acima que sua teoria pretende ser completa, de modo que isso parece ser uma indicação de que há outro princípio instrumental envolvido, a saber, o do plano inclinado, que será, entretanto, introduzido na quarta parte do texto, a partir do capítulo sobre o parafuso. Note-se, além disso, que o princípio que se acaba de enunciar pode ser entendido como princípio do funcionamento da alavanca.

Na demonstração que apresenta - [161]-[162] -, Galileu pretende não apenas ter demonstrado ser verdadeiro o princípio da proporcionalidade inversa entre peso e distância ou princípio da alavanca, mas também a equivalência entre este princípio e o princípio da balança, isto é, que é o mesmo "suspender pesos desiguais a distâncias de proporções inversas, que pesos iguais a distâncias iguais" [161].

Cabe aqui fazer dois comentários. O primeiro diz respeito ao sentido de "demonstração" empregado por Galileu neste contexto de exposição do princípio da alavanca, que significa ilustrar, mostrar, e algumas vezes confirmar experimentalmente o 
princípio exposto. Ora, esse procedimento faz parte do estilo de exposição científica que Galileu continuará a empregar mais tarde nos Discorsi (cf. Mariconda \& Vasconcelos, 2006, p. 210-26). Esse estilo consiste basicamente em apresentar o princípio de uma teoria e depois um experimento básico que confirma o princípio. O segundo comentário visa chamar a atenção para a importância instrumental da equivalência entre a alavanca e a balança.

Nas Advertências - [163]-[165]-que seguem a exposição do princípio da alavanca, Galileu introduz duas considerações. A segunda, menos importante teoricamente, tem relevância prática, porque visa a determinar "de que maneira devem ser medidas" as distâncias a que se refere o princípio e chega à seguinte regra prática: "que as distâncias sejam medidas com linhas, que caiam em ângulos retos sobre aquelas nas quais os graves estão pendentes, e sobre as quais se moveriam quando descessem livremente" [165].

A primeira advertência, entretanto, diz respeito ao efeito da velocidade e é extremamente importante, pois acaba provendo o princípio da proporcionalidade inversa de uma interpretação que torna possível entendê-lo em termos de deslocamentos virtuais em um quadro que já se apresenta, de certo modo, como inercial. Com efeito, Galileu inicia a advertência anunciando a confirmação do princípio por meio de outra congruência, que consiste em considerar a situação experimental de uma balança na qual pesos diferentes estão equilibrados a distâncias inversamente proporcionais aos pesos. Nessa situação, "se a um deles fosse acrescentado um mínimo momento de gravidade" [163], isso seria suficiente para fazer a balança mover-se, deslocando-se para baixo o peso que recebeu o acréscimo insensível e para cima o outro. Ora, se para mover o peso "é suficiente acrescentar-lhe uma mínima gravidade, por isso, sem levar em conta esse [peso] insensível, não haverá diferença entre poder um peso sustentar outro e poder movê-lo" [164]. Galileu afirma, portanto, existir uma indistinguibilidade entre equilíbrio (repouso) e movimento, de modo que uma mínima alteração na situação é suficiente para colocar os corpos em movimento.

$\mathrm{O}$ argumento de Galileu e sua afirmação da indistinguibilidade entre repouso e movimento mostram que ele já os considera como estados, nos moldes da concepção relativista do Diálogo, de modo que, nesta advertência, Galileu mostra ter completado a primeira etapa rumo à concepção relativista do movimento, que consiste na superação da dicotomia aristotélica entre repouso como estado e movimento como processo (cf. Mariconda \& Vasconcelos, 2006, p. 138-9). ${ }^{\mathbf{1 3}}$ Mas há no nosso tratado evidências mais concretas de que Galileu já se move no interior de um quadro amplamente inercial.

13Certamente este é o lugar para lembrar que As mecânicas tiveram seu desenvolvimento interrompido em 1602 e, portanto, não se beneficiaram da descoberta, em 1604, de que a velocidade de queda natural cresce proporcionalmente ao quadrado dos tempos; o que obrigaria a alterar, por exemplo, a consideração, que se mantém por toda 
Talvez em virtude de uma dificuldade interna de exposição e muito provavelmente até de desenvolvimento da teoria, Galileu não parece ter resolvido a questão de mostrar a equivalência entre o princípio da alavanca, que acabamos de expor, e o princípio do plano inclinado, de modo a poder reduzir o parafuso, a cóclea de Arquimedes e a cunha, que dependem do plano inclinado, ao princípio instrumental da alavanca. Reencontra-se, desse modo, uma nova discussão da virtualidade do movimento no início da quarta parte - de [179] a [183] -, quando Galileu introduz o princípio instrumental do plano inclinado, iniciando pelo parafuso, e retoma a discussão da virtualidade do movimento, reformulando-a para o plano inclinado.

Galileu inicia sua apresentação da base e fundamento do parafuso reafirmando a suposição dinâmica geral, segundo a qual "a constituição da natureza no tocante aos movimentos das coisas graves é tal que qualquer corpo, que retenha em si gravidade, tem a propensão de mover-se, se for liberado, em direção ao centro [da Terra]" [179]. Essa suposição é central para a caracterização da situação experimental na qual Galileu argumentará.

Tendo em vista que a situação experimental idealizada descrita por essa passagem de As mecânicas é retomada exatamente da mesma maneira na célebre passagem do Diálogo sobre os dois máximos sistemas do mundo (cf. Galilei, 2001 [1632], p. 171-4) na qual Galileu apresenta sua concepção inercial, cito integralmente a passagem:

Desse modo, se temos uma superfície muito bem tersa e polida, como seria aquela de um espelho, e uma bola perfeitamente redonda e lisa, ou de mármore, ou de vidro, ou de matéria similarmente apta a ser polida, esta, colocada sobre a dita superfície, começará a mover-se, desde que aquela tenha um pouco de inclinação, ainda que mínima, e somente parará sobre aquela superfície que seja exatissimamente nivelada, e equidistante do plano do horizonte, tal como seria, por exemplo, a superfície de um lago ou de um charco congelado, sobre a qual o corpo esférico estaria parado, mas com a disposição de ser movido por qualquer força pequeníssima. Porque, tendo entendido como, se tal plano se inclinasse somente quanto é [a espessura de] um cabelo, a dita bola aí se moveria espontaneamente em direção à parte em declive e, ao contrário, teria resistência, nem se poderia mover sem alguma violência, em direção à parte em aclive ou ascendente; fica necessariamente claro que na superfície exatamente equilibrada a bola permanece como que indiferente e dúbia entre o movimento e o repouso, de modo que qualquer mínima força é suficiente para movê-la, assim como, ao contrário, 
qualquer mínima resistência, tal como apenas aquela do ar que a circunda, é suficiente para mantê-la parada [179]-[180].

Há várias coisas a comentar nessa passagem. A primeira e mais geral consiste em considerar que Galileu não está propondo um “experimento de pensamento”, irrealizável praticamente, pelo qual idealiza a situação de modo a poder matematizá-la e a extrair um princípio a priori, mas, a meu ver, está propondo condições de idealização, que procuram eliminar os acidentes externos, tais como o atrito, com vistas a assegurar a possibilidade de matematização em uma situação experimental efetiva de controle das variáveis externas. De que outro modo entender que a cada condição de idealização apresentada, Galileu apresente o objeto correspondente a ser utilizado no experimento? Assim, à "superfície muito bem tersa e polida" corresponde o espelho e à "bola perfeitamente redonda e lisa" corresponde a bola de vidro ou de mármore e à superfície "exatissimamente nivelada, equidistante ao plano do horizonte" corresponde "a superfície de um lago ou de um charco congelado”. Parece, portanto, que Galileu não está só descrevendo uma situação idealizada, mas aponta para a realização efetiva de experimentos com bolas de mármore e vidro e com espelhos. São a estes experimentos que Galileu volta a referir-se mais tarde na Quarta Jornada dos Discorsi, quando descreve o método de traçar arcos de parábolas mediante o lançamento de bolas de mármore em espelhos, de modo que as bolas deixem no espelho a impressão de sua trajetória.

O segundo comentário diz respeito à insistência de Galileu na utilização de infinitesimais, tais como "força pequeníssima", "[espessura de] um cabelo", "mínima força", "mínima resistência". As condições de idealização do experimento são tais que exigem o uso e o desenvolvimento da análise infinitesimal, Este aspecto é importante porque mostra que a investigação sobre a resistência dos materiais exposta na Segunda Jornada dos Discorsi está em clara linha de continuidade com a teoria das máquinas de As mecânicas. Sem poder apresentar em maior profundidade este importante ponto, limito-me aqui a lembrar a importância da introdução da noção de "mínimos incrementos" e de "mínimas diferenças" para a versão galileana do princípio dos deslocamentos virtuais e para a perspectiva dinâmica que Galileu adotará em sua análise do funcionamento dos instrumentos mecânicos.

Por fim, cabe comentar a reafirmação da indistinguibilidade entre repouso e movimento agora reformulada para o plano inclinado. Nas condições ideais postas, "na superfície exatamente equilibrada", vale dizer, naquela superfície perfeitamente nivelada, que não é aclive nem declive, "a bola permanece como que indiferente e dúbia entre o movimento e o repouso". Ora, essa situação experimental idealizada e a indistinguibilidade entre repouso e movimento permitem que Galileu extraia duas consequências. A primeira consiste, na formulação de Galileu, em: 
tomar, como axioma indubitável, (...) que os corpos graves, removidos todos os impedimentos externos e adventícios, podem ser movidos no plano do horizonte por qualquer mínima força [180].

Note-se que movimento e repouso são tomados como estados que podem ser alterados por mínimas alterações das condições externas. Note-se também que Galileu não faz qualquer afirmação concernente à velocidade, se ela é uniforme ou sofre alteração; tampouco explica se a tendência de mover-se, que o corpo tem na horizontal quando recebe um pequeno impulso, mantém-se indefinidamente. E o fato de o movimento ser retilíneo está subentendido na restrição ao plano horizontal. Pode-se, portanto, dizer que há um “déficit” de conceituação inercial na argumentação galileana; entretanto, parece estar completa a concepção relativista do movimento, na qual movimento e repouso são estados mutuamente relativos e o movimento só depende da mudança nas relações espaço-temporais dos corpos, e que servirá de base conceitual mecânica para a defesa do movimento da Terra no Diálogo.

Deve-se também levar em consideração que uma vez introduzido o axioma que lhe permite dar um tratamento dinâmico à questão da continuidade do movimento no plano horizontal, Galileu não se interessa por desenvolver as consequências dinâmicas ou em discutir o próprio fundamento teórico, mas por razões técnicas ligadas ao próprio desenvolvimento do tratado, está interessado na força que se deve despender para elevar o peso pelo plano inclinado, de modo que extrai como segunda consequência da situação experimental que

os corpos graves possuem maior resistência a serem movidos sobre planos diferentemente elevados, segundo um seja mais ou menos elevado que o outro e, finalmente, ser grandíssima a resistência do mesmo grave a ser alçado pela perpendicular [180].

A passagem [181]-[182] está dedicada a investigar "a proporção que deve ter a força para o peso, para puxá-lo sobre planos inclinados diferentes" e conduz à formulação do princípio instrumental básico do plano inclinado, ou seja, à proposição universal de que "sobre o plano inclinado, a força tem para o peso a mesma proporção que a perpendicular do término do plano até a horizontal tem para o comprimento desse plano" [183] ou, o que é o mesmo, que a força tem para o peso a mesma proporção que a altura do plano tem para sua extensão.

Com isso se encerra a discussão daquela parte de As mecânicas que se dedica à fundamentação física-matemática da teoria da máquina simples. Vejamos agora como sobre estes fundamentos Galileu apresenta as duas famílias de instrumentos mecânicos. 


\subsubsection{As FAmílias DE INSTRUMENTOS LIGADOS À ALAVANGA E AO PLANO INGLINAdo}

As duas partes finais compõem a parte propriamente técnica do tratado e dedicam-se à exposição do funcionamento e propriedades dos instrumentos mecânicos. Cada uma delas segue o mesmo estilo de composição. Parte de um princípio que define o funcionamento de uma divisa instrumental básica, no caso, a alavanca e o plano inclinado, para explicar uma família de divisas mecânicas que consistem em aplicações simples da divisa básica.

Note-se que isso proporciona também uma caracterização de máquina simples por redução ao funcionamento de uma divisa instrumental de base, alavanca ou plano inclinado, de modo que o funcionamento de qualquer instrumento de uma família pode ser explicado pelo princípio que preside o funcionamento da alavanca ou do plano inclinado. No que segue, não farei mais que apresentar esquematicamente como se organiza a exposição de Galileu em cada caso.

No caso da família dos instrumentos que se originam no princípio da alavanca da proporcionalidade inversa entre peso e distância, Galileu mostra primeiro como o princípio se aplica imediatamente à balança romana ou de braços desiguais e à alavanca. Cabe lembrar que o uso simples da alavanca explica uma extensa gama de instrumentos simples de amplo uso cotidiano, tais como pinças, quebra-nozes, carrinho de mão, trincos e travas etc. Talvez por isso Heron de Alexandria, em As mecânicas ou o elevador dos corpos pesados, ${ }^{\mathbf{1 4}}$ considerasse a alavanca como o primeiro instrumento empregado pela humanidade desde os tempos imemoriais da pré-história. Passa a seguir a tratar dos instrumentos que fazem um uso especial da alavanca, que consiste na reiteração da aplicação da alavanca sobre um mesmo ponto de modo a perpetuá-la. Os instrumentos tratados são, primeiro, o eixo, que se reporta ao funcionamento da roda e do torno, e o cabrestante, que se reporta ao guindaste. Passa, então, às talhas para demonstrar primeiramente que elas operam como "outro modo de usar a alavanca" [171], a partir do que organiza sua exposição do ponto de vista da operação técnica envolvida, mostrando as propriedades das talhas (1) no inverter o sentido da força a ser empregada; (2) no duplicar a força; (3) no duplicar a força invertendo sua aplicação; (4) na multiplicação das forças "segundo qualquer multiplicidade que se queira" [175], mostrando primeiro como duplicar a força e depois como triplicá-la, de modo que combinando os modos duplo e triplo se consegue qualquer multiplicação desejada de forças.

No caso da família dos instrumentos que se originam do princípio do plano inclinado, segundo o qual a força está para o peso ou a resistência assim como a altura do

14. Heron afirma isso na apresentação da alavanca, segundo instrumento simples, do Livro II de seu famoso texto intitulado As mecânicas ou o elevador de corpos pesados (cf. Heron de Alexandria, 1988 [1894], p. 116-7). 
plano inclinado está para seu comprimento, Galileu inicia a exposição com o longo preâmbulo-[178]-[185]-, que já analisamos acima, e passa depois à natureza do parafuso, explicando o funcionamento do plano inclinado, quando usado como uma cunha que, movida por baixo de um corpo, pode alçá-lo, fazendo-o subir pelo plano inclinado. Mostra a seguir como isso pode ser transformado em uma máquina "reduzida a uma forma mais pequenina e cômoda”, quando o triângulo (ou plano inclinado) é aplicado sobre o cilindro, gerando neste uma linha helicoidal, operação que produz o parafuso, no qual a força se multiplica segundo a proporção com que o comprimento de todo o verme do parafuso excede a altura (cf. [184]). Depois de apresentar a regra para descobrir quanto de força um parafuso multiplica, discute-se também o uso das porcas.

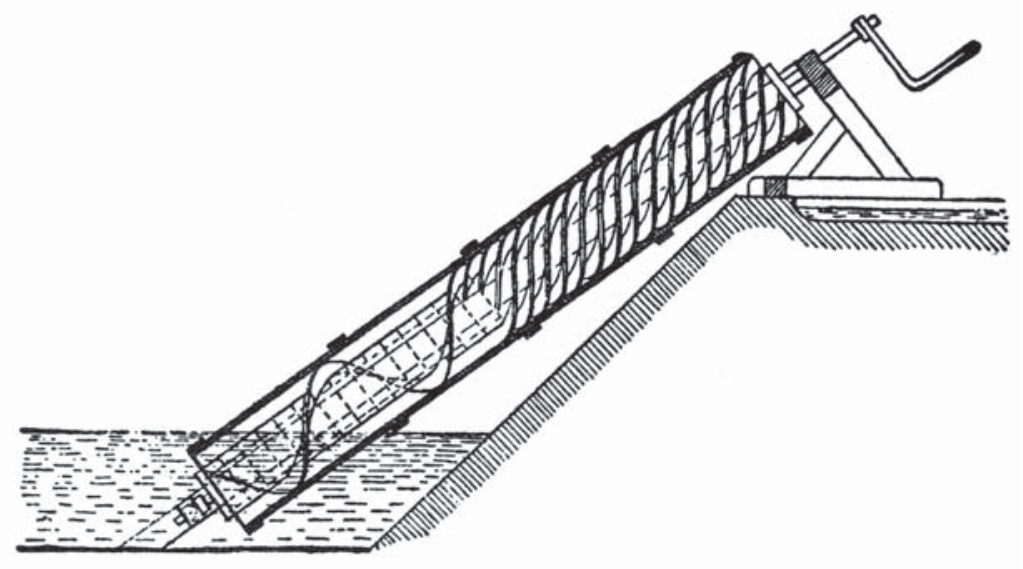

Figura 7. A cóclea foi um instrumento de amplo uso principalmente na Antiguidade latina. Os romanos as utilizavam para as drenagens das minas.

Galileu discute a seguir a cóclea ou parafuso de Arquimedes, que é produzido pela aplicação a um cilindro de um triângulo retângulo que tenha a altura do cilindro e sua hipotenusa, ou plano inclinado, forme um ângulo de $3 \circ^{\circ}$ (terça parte de um ângulo reto) ou de $25^{\circ}$ (quarta parte de um ângulo reto) com a base, de modo que se sulque um canal helicoidal (verme) contínuo com a inclinação de $30^{\circ}$ ou $25^{\circ}$. Esse instrumento, quando mergulhado na água de um lago ou canal com uma inclinação ligeiramente superior a $30^{\circ}$ ou $25^{\circ}$ e girado, produz o efeito de fazer a água subir "no parafuso descendo continuamente" [186], de modo que permite facilmente retirar água de um lugar mais baixo e transportá-la para um lugar mais alto. Galileu explica seu funcionamento demonstrando a regra prática, segundo a qual "o parafuso, para alçar a água, deve estar um pouco mais inclinado que a quantidade do ângulo do triângulo, com o qual se descreveu esse parafuso" [187]. 
O tratado conclui com uma investigação da força de percussão, no que se pode considerar como uma espécie de anexo especulativo, no qual Galileu investiga a operação mecânica do martelo, instrumento cujo funcionamento é de difícil redução seja à alavanca, seja ao plano inclinado. Essa mesma investigação será retomada de modo mais aprofundado, mas ainda bastante inconclusivo, na jornada postumamente publicada, comumente chamada de Sexta Jornada, dos Discorsi.

Cabe, por fim, um último comentário acerca da estrutura argumentativa do tratado. Ao apresentar o parafuso de Arquimedes, Galileu surpreendentemente afirma que a "invenção não só é maravilhosa, como miraculosa, pois encontraremos que a água sobe no parafuso descendo continuamente"; ou seja, a invenção é miraculosa, pois tem o efeito aparentemente paradoxal de subir descendo. Não estaria isso contradizendo a posição inicial de que não há milagre nas máquinas, de que por meio delas não se engana a natureza? Não estaria Galileu substituindo, por assim dizer, a concepção milagrosa dos mecânicos vulgares pela concepção milagrosa de Arquimedes?

A primeira coisa a notar é que, na verdade, a afirmação de Galileu tem o objetivo retórico de servir de contraponto da concepção vulgar, porque a negação da visão vulgar não significa a negação de soluções técnicas admiráveis, de modo que o efeito miraculoso da cóclea de Arquimedes, que é sem dúvida uma solução técnica admirável, é perfeitamente explicável em termos do princípio do plano inclinado. Assim, o admirável agora é conseguir o efeito paradoxal respeitando a regra instrumental de base a qual está de acordo a uma regularidade natural. Mas há ainda outro aspecto que reforça o papel retórico de contraponto da afirmação de Galileu de que soluções técnicas podem ser admiráveis, embora as máquinas não funcionem contra a natureza. Uma leitura atenta do tratado revela que em cada um dos capítulos dedicados às exposições dos funcionamentos das máquinas, Galileu reitera o contraponto à visão vulgar. Assim, no capítulo sobre a balança romana e a alavanca, afirma que a utilidade desses instrumentos

não é aquela da qual se persuadem os mecânicos vulgares, isto é, que se acaba por superar e, de certo modo, enganar a natureza, vencendo com pequena força uma resistência grandíssima com a intervenção da alavanca, porque demonstraremos que se teria obtido o mesmo efeito, sem a ajuda do comprimento da alavanca, com a mesma força, no mesmo tempo [166].

Reitera essa explicação com um pouco mais de detalhe no capítulo sobre o eixo da roda e o cabrestante: 
Tanto neste, como no outro instrumento, nota-se aquilo que várias vezes se afirmou, a saber: a utilidade que dessas máquinas se obtém não é aquela na qual o vulgo acredita comumente, enganando-se, acerca dos mecânicos, isto é, que se possa, defraudando a natureza, com máquinas superar a sua resistência, ainda que grande, com pequena força; sendo que deixaremos evidente como a mesma força posta em $F$, no mesmo tempo, fazendo o mesmo movimento, conduzirá o mesmo peso, na mesma distância, sem máquina alguma [170].

Nos dois capítulos seguintes, Galileu substitui as formulações mais longas, como as acima, por uma formulação mais breve, que consiste, no capítulo sobre as talhas, em assinalar que "tal como nos outros instrumentos, neste também, quanto se ganha de força, tanto se perde de velocidade" [172], e no capítulo sobre o parafuso em advertir que

não se deve deixar em silêncio aquela consideração, a qual se disse, ao início, ser necessária de existir em todos os instrumentos mecânicos, a saber, que quanto se ganha em força por meio deles, outro tanto se perde no tempo e na velocidade [185].

Quando logo depois Galileu volta a referir-se ao admirável e milagroso da invenção mecânica do parafuso para elevar água, a contraposição atinge seu ponto máximo, permitindo agora que Galileu se aproprie do surpreendente em um contexto moderno de explicação do funcionamento das máquinas.

\subsection{O AlGance de As mecânicas de Galileu}

Grande parte do interesse do tratado de Galileu reside no fato de que para ele convergem duas perspectivas históricas de análise e interpretação. Assim, o texto de As mecânicas, quando visto nessa convergência, revela essas duas perspectivas de estudo do desenvolvimento da mecânica: de um lado, a perspectiva científica, mais teórica; de outro, a perspectiva técnica, eminentemente prática. Resumidamente, pode-se dizer que a perspectiva científica visa a história da constituição da mecânica teórica, sem necessário correlato prático. Sua preocupação é com a reconstituição do processo de constituição conceitual e teórica da estática. A questão central consiste, por exemplo, em perguntar-se no que o tratamento dinâmico dado por Galileu à estática contribuiu para a constituição da disciplina da estática ou para a constituição de conceitos, tais como o de trabalho, ou de princípios, como o de conservação de energia. De outra parte, a perspectiva técnica visa a história da investigação mecânica enquanto ligada ao desenvolvimento efetivo das máquinas. Sua preocupação é com a prática e revela-se 
claramente na importância dada à efetividade da aplicação, isto é, na possibilidade de desenvolvimento do projeto ou desenho experimental e técnico. A questão central nesta perspectiva consiste em inquirir no que o tratamento dado por Galileu às máquinas contribuiu para o desenvolvimento do meio ou sistema técnico moderno. No que contribui, digamos, para o avanço da compreensão da máquina e do seu funcionamento? Veremos nesta seção três posições relativas à contribuição e ao alcance do texto de Galileu, apresentando primeiramente a posição de Drake, que o avalia da perspectiva de sua contribuição para o desenvolvimento interno das concepções científicas de Galileu, a seguir, a posição de Clavelin, que o considera da dupla perspectiva de sua contribuição à estática e à técnica e, por fim, a posição de Cardwell, que o toma de uma perspectiva estritamente técnica.

Drake adota a perspectiva estritamente interna de avaliar a contribuição de $A s$ mecânicas para a constituição das próprias concepções científicas de Galileu (cf. Drake, 1958; 1988, p. 95-102). Nesse sentido, sua avaliação atém-se rigorosamente à distinção entre o desenvolvimento das concepções "na mente de Galileu" e o desenvolvimento histórico geral dessas concepções. Para ele, "a importância científica de As mecânicas reside no emprego de concepções dinâmicas nas análises de estática e na história das concepções inerciais e da conservação do trabalho" (Drake, 1958, p. 266). Ou seja, três aspectos devem ser levados em consideração, para proceder à avaliação da contribuição científica do tratado, a saber, primeiro, o tratamento dinâmico das questões estáticas, depois, as concepções inerciais e, finalmente, as ideias ligadas à conservação do trabalho.

Com relação ao primeiro aspecto, Drake considera que o que torna possível seja o tratamento dinâmico dado por Galileu à estática, seja o estabelecimento "do princípio das velocidades virtuais em um fundamento firme" é a concepção de que corpos em equilíbrio ou em repouso podem ser postos em movimento por uma mínima força, que é desprezível para fins de elaboração teórica ou, como diz Drake (1958, p. 267), "que poderia ser ignorada para os propósitos da mecânica teórica", de modo que o princípio teria um uso em contextos eminentemente práticos. Entretanto, Drake não aprofunda seu comentário, de modo que deixa em aberto, no tocante a este primeiro aspecto, a seguinte questão: teria Galileu dado um tratamento dinâmico às questões, tendo em vista que ele estava menos interessado no desenvolvimento científico da estática, enquanto ciência do equilíbrio, e mais interessado na fundamentação estática do funcionamento das máquinas? Ou, de modo talvez mais claro, não estaria Galileu mais interessado em explicar o funcionamento das máquinas do que em estabelecer a ciência da estática?

Quanto às concepções inerciais desenvolvidas em As mecânicas - que, na seção 3.1.2 desta introdução, foram referidas à tese da indistinguibilidade entre repouso e 
movimento para um sistema de corpos em equilíbrio (ou para um corpo parado sobre um plano horizontal) e à concepção de que um mínimo de força ou de momento é suficiente para pôr o sistema ou o corpo em movimento -, Drake considera que elas pertencem à origem da concepção inercial na mente de Galileu, de modo que a concepção inercial tem verdadeiramente origem na mecânica e não na cosmologia (cf. Drake, p. 267), embora o desenvolvimento histórico do conceito tenha ocorrido no contexto da disputa sobre a astronomia e a cosmologia de Copérnico, em grande parte, justamente devido à própria discussão do quadro inercial, empreendida por Galileu no Diálogo em defesa do movimento da Terra. Isto é importante porque mostra que as concepções inerciais e relativistas originam-se na mecânica, na solução dos problemas de fundamentação estática das máquinas, nas tentativas de resolver o problema da proporção em que ocorre a aceleração na queda livre e constituem o quadro conceitual geral de todas as investigações mecânicas de Galileu, conduzindo por essa via a uma unificação dos enfoques mecânicos da estática e da dinâmica, no caso do tratado das máquinas.

Finalmente, Drake vê em As mecânicas o início de uma noção de conservação que se manifesta de dois modos: seja na insistência de Galileu "em uma relação recíproca exata entre a força aplicada e a distância atravessada (ou velocidade do movimento)" (Drake, 1958, p. 267), seja na tentativa de encontrar um princípio para analisar a força de percussão. Entretanto, o tom lacônico da afirmação mantém-se mesmo mais tarde na obra dedicada à biografia científica de Galileu (cf. Drake, 1988), de modo que ela fica mais como uma sugestão de que a relação inversa entre força e tempo representa uma primeira aproximação ao conceito de trabalho.

Como se vê, Drake avalia apenas a importância do texto sobre as máquinas para a constituição e desenvolvimento das próprias concepções de Galileu. Uma perspectiva

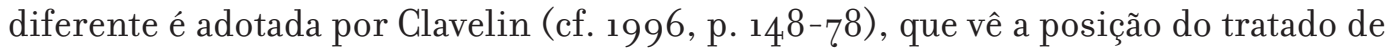
Galileu frente à tradição dos estudos na ciência do equilíbrio, ou seja, analisa o tratado comparando-o às realizações estáticas de seus principais predecessores (Aristóteles, Arquimedes, Nemorarius) e contemporâneos (Guidobaldo del Monte, Benedetti), tendo em vista o duplo caráter do texto - científico e técnico.

Para Clavelin, As mecânicas mostram sinais claros da confluência de três tradições distintas da pesquisa na estática: a corrente das Questões mecânicas, falsamente atribuída a Aristóteles, mas que pertence a sua escola, a corrente que se liga a Arquimedes e a corrente medieval ligada a Jordanus Nemorarius; três tradições que Galileu amalgama em uma síntese para "construir uma teoria ordenada e raciocinada das máquinas simples" (Clavelin, 1996, p. 148). Da primeira tradição, Galileu retira a ideia de explicar as máquinas simples por redução ao princípio da alavanca; da segunda retira a noção de centro de gravidade, que já vimos estar na base das idealizações com as quais Galileu pode geometrizar as situações mecânicas; da terceira, Galileu obtém a análise 
das velocidades virtuais e o princípio do plano inclinado (cf. Clavelin, 1996, p. 1486o). Entretanto, para ele, Galileu consegue em As mecânicas uma assimilação e um domínio tão completos da tradição, que o texto se constitui no "primeiro tratado de estática verdadeiramente moderno" (1996, p. 169).

Quanto à contribuição técnica de As mecânicas, Glavelin considera que ela se encontra nas condições ideais que Galileu impõe a sua análise, as quais o conduziram “a considerar como infinitamente pequena a impulsão adicional necessária para produzir um movimento com a ajuda de uma máquina simples, e mostram assim pela primeira vez como o estudo dessas máquinas depende da estática" (Clavelin, 1996, p. 178, cf. 1998, p. 253). Entretanto, embora Clavelin reconheça o caráter técnico do tratado sobre as máquinas, quando se trata de avaliar seu alcance técnico, ele se resume, de certo modo, a afirmar a importância da ciência (no caso, a estática que acaba de receber sua expressão científica moderna) para o estudo das máquinas, deixando de analisar a contribuição na esfera propriamente técnica. Na verdade, isso se explica porque Clavelin também está preso à dimensão interna da constituição das concepções de Galileu, de modo que está obrigado a avaliar As mecânicas face ao conjunto da obra mecânica do famoso pisano. Seu argumento e juízo a esse respeito é claro: As mecânicas revelam que o período de formação de Galileu está completo, que ele "tem a exata medida dos recursos e das exigências do método geométrico para a análise dos problemas físicos" (Clavelin, 1996, p. 178).

Diferentemente de Drake e Clavelin, que avaliam o alcance ou contribuição do tratado à luz da perspectiva científica e da análise da inteligibilidade interna da obra de Galileu, Cardwell se coloca estritamente da perspectiva técnica, pois se propõe a apresentar em seu livro os turning points que deram forma à tecnologia ocidental. Para ele, "é certamente impossível entender o desenvolvimento da tecnologia moderna sem algum entendimento da mecânica de Galileu, da termodinâmica de Sadi Carnot, Kelvin e Clausius e da teoria do campo de Faraday e Maxwell" (Cardwell, 1972 , p. ix). A posição de Cardwell consiste em considerar que Galileu é o fundador da tecnologia moderna. Vou ficar circunscrito aqui a sua avaliação da contribuição técnica de As mecânicas.

No que se refere à ciência das máquinas, a tese geral de Cardwell é que a principal contribuição do texto de Galileu consiste na modificação produzida na própria caracterização de máquina, ou seja, na substituição promovida por Galileu da imagem qualitativa pela imagem quantitativa de máquina. Na imagem qualitativa, "acede-se à qualidade de uma máquina por meio de padrões puramente normativos: está bem construída e é feita de bons materiais? Serve ao seu propósito (...)? É esteticamente satisfatória ou revela ainda engenhosidade e sagacidade?" (Cardwell, 1972, p. 37). Além do mais, a imagem qualitativa está apta à interpretação de que as máquinas operam enganando a natureza. Para Galileu, ao contrário, "a função da máquina é desdobrar e usar 
os poderes que a natureza torna disponível da melhor maneira possível para os propósitos humanos" (p. 38), de modo que a performance, o rendimento ou o trabalho feito por uma máquina passa a ser avaliado em outros termos. Para mostrar como Galileu realiza essa transição para a imagem quantitativa de máquina, Cardwell analisa dois aspectos que considera fundamentais do aporte técnico do tratado.

O primeiro aspecto é responsável pelo diferencial do tratado de Galileu com relação aos trabalhos dos antecessores e consiste na estratégia de Galileu de introduzir condições de idealização com o objetivo basicamente de eliminar o atrito, de modo a pensar uma máquina ideal. Os antecessores de Galileu sabiam que "o atrito reduz a performance [o rendimento] de uma máquina, mas nenhum deles tinha sido conduzido a, ou tinha sido capaz de, pensar o problema: o que deve acontecer com uma máquina perfeita?" (Cardwell, 1972, p. 40), ou, de modo mais simples, o que aconteceria com uma máquina que funcionasse sem atrito? Ou ainda melhor, embora Cardwell não chegue a considerar essa possibilidade, que está claramente presente, como vimos, na tentativa de Galileu de aproximar o caso concreto das condições de idealização: o que acontece com uma máquina na qual diminuímos experimentalmente (por aproximação do desenho experimental às condições ideais) o atrito e outros tipos de resistências e efeitos? Ora, se refletimos como Galileu sobre uma tal máquina ideal, "então é fácil ver que uma pequena força é suficiente para pôr a máquina lentamente em movimento" (Cardwell, 1972, p. 4,0). O primeiro passo dado por Galileu em direção à quantificação do conceito de máquina consiste, portanto, em considerar a máquina em condições ideais para as quais vale o que chamei de indistinguibilidade entre repouso e movimento, de modo que a máquina é alçada pelas condições ideais ao quadro inercial da mecânica. A primeira contribuição de Galileu para a técnica corresponde, assim, ao tratamento científico e explicativo com o qual Galileu torna ciência racional o discurso sobre as máquinas.

Mas concebida a situação idealizada, como se estuda agora a operação dinâmica da máquina? Como Galileu explica o funcionamento das máquinas? Em primeiro lugar, é preciso não esquecer o fato óbvio de que, do ponto de vista técnico, existem essencialmente dois componentes em qualquer máquina: o agente motriz e o mecanismo por meio do qual o esforço é transformado para atingir o fim desejado. Isto posto, o esquema básico de explicação empregado por Galileu consiste em "mostrar que o mecanismo de todas as máquinas pode ser reduzido a um sistema simples de alavancas" (cf. Cardwell, 1972, p. 39) ${ }^{\mathbf{1 5}}$ e em estender o princípio da alavanca do caso estático ao

15 Convém lembrar que, como mostramos na seção 3. 1. 2, As mecânicas não possuem tal unidade, sendo discutível que Galileu consiga (ou tenha mesmo o interesse de), no tratado, reduzir o princípio do plano inclinado e a suposição do efeito da velocidade na força de percussão ao princípio da alavanca. Mas, sem dúvida, o texto aponta para essa redução completa ao princípio da alavanca. 
dinâmico, por meio da consideração do efeito da velocidade na potência motriz, sendo que o produto do peso de um corpo por sua velocidade é tomado por Galileu como uma medida da potência que está sendo empregada. Cardwell considera, neste ponto, que Galileu realiza um segundo passo importante rumo à imagem quantitativa de máquina, pois isso "significa que com qualquer agente particular o efeito, desde que possamos ignorar as perdas decorrentes do atrito, deve sempre ser quantitativamente o mesmo, sem importar a máquina que é aplicada" (Cardwell, 1972, p. 411; cf. Halleux, 1998, p. $5^{87}$ ). Com efeito, é fácil comprovar que Galileu insiste a cada capítulo de As mecânicas, contra a imagem qualitativa de máquina, que se pode com a mesma força realizar no mesmo tempo o mesmo deslocamento sem máquina alguma; o que significa obviamente que onde "a 'força' aplicada é, em cada caso, a mesma, pelos princípios de Galileu, o trabalho feito, em cada caso, é também o mesmo" (p. 411).

Assim, para a concepção de máquina de Galileu, todas elas têm a função de transmitir e aplicar a força ou a potência tão eficazmente quanto possível. Nessa concepção é possível desenvolver a avaliação quantitativa do desempenho das máquinas em termos do produto da força motriz empregada por sua velocidade, o que corresponde a um passo importante em direção à quantificação da potência de uma máquina, abrindo “o caminho para a elaboração de conceitos tais como trabalho e energia" (p. 42), fundamentais para o desenvolvimento da engenharia moderna. Entretanto, o alcance da imagem quantitativa de máquina que se articula em As mecânicas não se resume à avaliação quantitativa do rendimento das máquinas, mas produz também uma alteração na própria maneira de estudar as máquinas, inventando um novo tipo de estratégia para o qual "o desenho e a função de cada componente podem ser estudados sem consideração do propósito final ao qual serve a máquina" (Cardwell, 1972, p. 43). Tanto a estratégia, quanto a matematização que a preside serão fundamentais para o desenvolvimento técnico posterior das máquinas. Finalmente, As mecânicas são também uma evidência de como a formulação das leis do movimento na mecânica deve muito à consideração das máquinas.

Pode-se dizer, em conclusão, que As mecânicas, com as quais se inicia o desenvolvimento da perspectiva técnica moderna, são a expressão mais cabal da união entre a ciência e a técnica, a ponto de que elas proporcionam um mesmo fundamento para a estática e para a teoria das máquinas simples. Temos, assim, um tratado científico de estática que também pode servir como manual técnico sobre as máquinas simples.@

Agradecimentos. Este texto foi desenvolvido como parte da pesquisa do Projeto Temático "Gênese e significado da tecnociência”, financiado pela Fapesp. Parte dele foi apresentado no vi Encontro da Associação de Filosofia e História da Ciência do Cone Sul (AFHIC), realizado em Montevidéu em maio de 2008. Ambos os financiamentos foram importantes para a elaboração deste texto, de modo que expresso aqui meu agradecimento à Fapesp pelos auxílios recebidos. 


\section{Pablo Rubén Mariconda}

Professor Titular de Teoria do Conhecimento e Filosofia da Ciência, Departamento de Filosofia, Universidade de São Paulo, Brasil. ariconda@usp.br

\section{REFERÊNGIAS BIBLIOGRÁFIGAS}

Adam, C. \& Tannery, P. (Ed.). Oeuvres de Descartes. Paris: Vrin/Centre National Du Livre, 1995-1998. 11 v. (AT)

Aristóteles. Mechanics. In: Barnes, J. (Ed.). The complete works of Aristotle. Princeton: Princeton University Press, 1991.v. 2, p. 1299-318. (Mech)

Barnes, J. (Ed.). The complete works of Aristotle. Princeton: Princeton University Press, 1991. 2 v.

Blay, M. \& Halleux, R. (Ed.). La science classique - ХИІе-ХИIIIe siècle. Paris: Flammarion, 1998.

CARdweld, D. S. L. Turning points in western technology. New York: Science History Publications, 1972.

Carneiro, F. L. Galileu e os efeitos do tamanho. Ciência Hoje, 9, 50, p. 31-9, 1989.

Clavelin, M. La philosophie naturelle de Galilée. Paris: Albin Michel, 1996.

Galilée. In: Blay, M. \& Halleux, R. (Ed.). La science classique - ХИIe-ХVIIIe siècle. Paris: Flammarion, 1998. p. $252^{-6}-6$.

Drake, S. The earliest version of Galileo's mechanics. Osiris, 13, p. 262-90, $195^{8}$. . Galileo. Una biografia scientifica. Bologna: Il Mulino, 1988.

Favaro, A. (Ed.). Edizione nazionale delle opere di Galileo Galilei. Firenze: Barbera, 1933 [1891]. 20 v. (EN) . Avvertimento. In: (Ed.). Edizione nazionale delle opere di Galileo Galilei. Firenze: Barbera, 1933 [1891].v. 2, p. 149-54.

Galilei, G. Delle meccaniche lette in Padova l'anno 1594, da Galileo Galilei per la prima volta pubblicate ed illustrate da Antonio Favaro. Memorie del Reale Istituto Veneto di Scienze, Lettere ed Arti, 26, 5, 1899 [1594].

. Le mecaniche. In: Favaro, A. (Ed.).Edizione nazionale delle opere di Galileo Galilei. Firenze: Barbera, 1933. v. 2, p. 155-90.

Discorsi e dimostrazioni matematiche intorno a due nuove scienze. In: Favaro, A. (Ed.). Edizione nazionale delle opere di Galileo Galilei. Firenze: Barbera, 1933 [1638]. v. 8, p. 39-313.

. Le mecaniche. In: Gatтo, R. Galileo Galilei. Le mecaniche. Firenze: Olschki, 2002. p. 45-77.

Duas novas ciências. Tradução L. Mariconda \& P. R. Mariconda. São Paulo: Istituto Italiano di Cultura \& Nova Stella, 1985 [1638].

Diálogo sobre os dois máximos sistemas do mundo ptolomaico e copernicano. Tradução, introdução e notas P. R. Mariconda. São Paulo: Discurso Editorial / Fapesp, 2001 [1632].

Gatto, R. Consideraciones sobre Las mecánicas de Galileo. In: Montesinos, J. (Ed). Galileo y la gestación de la ciencia moderna. Canarias: Fundación Canaria Orotava de Historia de la Ciencia, 2001a. p. $187^{-203 .}$

. Sull' edizione critica de Le mecaniche di Galileo. In: Montesinos, J. \& Solís, G. (Ed). Largo campo di filosofare-EuroSymposium Galileo 2001. Canarias: Fundación Canaria Orotava de Historia de la Ciencia, 2001b. p. 203-15.

. Tra la scienza dei pesi e la statica. In: . Galileo Galilei. Le mecaniche. Firenze: Olschki, 2002. p. IX-CXLIV. 
Halleux, R. Machine. In: Blay, M. \& Halleux, R. (Ed.). La science classique - XVIe-XVIIIe siècle. Paris: Flammarion, 1998. p. 581-9.

Heron de Alexandria. Les mécaniques ou l'élévateur des corps lourds. Tradução B. G. de Vaux. Paris: Belles Lettres, 1988 [1894].

Mariconda, P. R. \& Vasconcelos, J. Galileu e a nova física. São Paulo: Odysseus, 2006.

Mersenne, M. Les mechaniques de Galilée. Paris: PUF, 1966 [1634].

Micheli, G. Le origini del concetto di macchina. Firenze: Olschki, 1995.

Montesinos, J. (Ed). Galileo y la gestación de la ciencia moderna. Canarias: Fundación Canaria Orotava de Historia de la Ciencia, 2001.

Montesinos, J. \& Solís, C. (Ed). Largo campo difilosofare - EuroSymposium Galileo 2001. Canarias: Fundación Canaria Orotava de Historia de la Ciencia, 2001.

Pappus de Alexandria. La collection mathématique. Tradução, introdução e notas P. V. Eecke. Paris: Albert Blanchard, 1982. v. 2.

Viviani, V. Racconto istorico della vita di Galileo Galilei. In: Favaro, A. (Ed.). Edizione nazionale delle opere di Galileo Galilei. Firenze: Barbera, 1933 [1691].v. 19, p. 597-632.

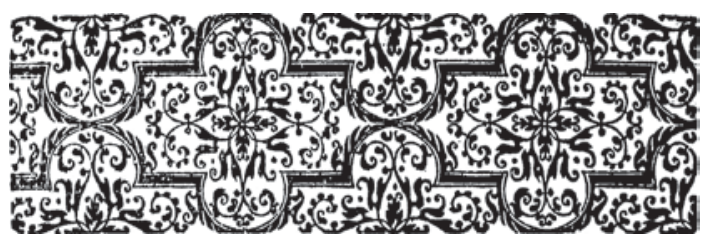

